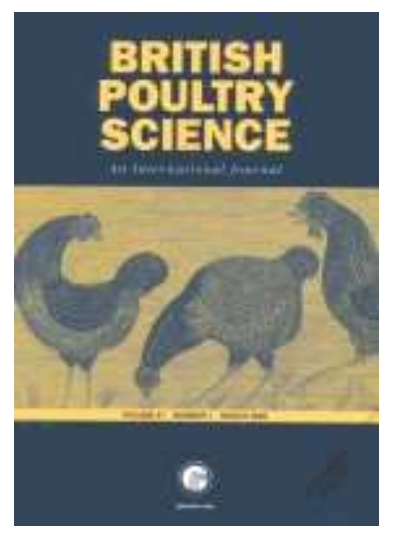

\title{
Economic, ecological, and social performance of conventional and organic broiler production in the Netherlands
}

\begin{tabular}{|r|l|}
\hline Journal: & British Poultry Science \\
\hline Manuscript ID: & CBPS-2008-110.R1 \\
\hline Manuscript Type: & Original Manuscript \\
\hline Date Submitted by the \\
Author: & 23-Dec-2008 \\
\hline Keywords: & $\begin{array}{l}\text { Brouplers, Welfare, sustainability assessment } \\
\text { Ge Boer, Imke; Wageningen University, Animal Production Systems }\end{array}$ \\
\hline &
\end{tabular}

\section{S) ScholarONE \\ Manuscript Central}


Economic, ecological, and social performance of

\section{$\underline{\text { conventional and organic broiler production in }}$}

\section{the Netherlands}

4

5

E.A.M. BOKKERS ${ }^{1}$, I.J.M. DE BOER

Deleted: Animal welfare measures in broiler production and their

economic, ecological and societal

6

7 Animal Production Systems Group, Department of Animal Sciences,

$11{ }^{1}$ Corresponding author

12 E.A.M. Bokkers

13 Tel. +31317483959 , Fax +31317485550

14 E-mail: eddie.bokkers@wur.nl 


\section{Abstract}

16 1. In this study, we compared a conventional broiler production system keeping fast

17 growing broilers with an organic broiler production system keeping slow growing

18 broilers in the Netherlands, both managed by one person working a full time year (Full

19

20 Time Equivalent, FTE). This comparison was based on a quantification of economic, acceptable for society ecological and social indicators, Indicators were quantified using scientific literature and national data sets.

2. The organic system performed better for the economic indicator net farm income per FTE than the conventional system.

3. Regarding ecological indicators, calculations showed a higher on-farm emission of ammonia per $\mathrm{kg}$ live weight for the organic system. Moreover, an organic system includes a higher risk for eutrophication per ha, due to outdoor access. Emission of green house gasses, use of fossil fuels and use of land required for the production of one $\mathrm{kg}$ of live weight is higher for an organic than for a conventional system. This is mainly due to a lower feed conversion in organic production and use of organic feed

4. The organic system performed better than the conventional system for the social, indicators related to animal welfare time spent on walking, footpad lesions, mortality, and sound legs. Regarding the social indicator food safety was found that meat from an organic system contained less antibiotic residues and Salmonella contaminations but more Campylobacter contaminations than meat from a conventional system.

5. Changing from a conventional to an organic, broiler production system, therefore, not only affects animal welfare, but also affects economic, ecological and other social issues. In this, study, we ran into the situation that some information needed was lacking in literature and quantifications had to be based upon several sources. Therefore, an integrated on-farm assessment is needed, which, can be used to develop a broiler production system that is economically profitable, ecologically sound, and
Formatted: Tabs: $14.2 \mathrm{pt}$, List tab + Not at $28.35 \mathrm{pt}$

Deleted: equivalent for

Deleted: societal issues in the Netherlands

Deleted: based on

Deleted: slow growing broiler production

Deleted: issues

Deleted: more ammonia

Deleted: and,

Deleted: , potentially more eutrophication

Deleted: the slow growing broiler

Deleted: system. Total fossil energy use is expected to be higher per bird in slow growing broilers because most fossil energy is used to produce feed

Deleted: slow growing broilers are less efficient in converting feed than

fast growing broilers. The latter is also a reason for higher land

Deleted: in organic broiler production, besides the fact that crop harvest per hectare is lower in general in

Deleted: production.

Deleted: slow growing broiler production

Deleted: all

Deleted: the societal issue Deleted: such as Deleted: foot

Deleted: another societal issue Deleted: ,

Deleted: the slow growing production system appeared to contain

Formatted

Deleted: over

Deleted: a slow growing

Deleted: has much more ... [2]

Deleted: for

Deleted: . Although it is difficu' ... [3] Deleted: the contribution to ... [4] Deleted:

Deleted: for that. In this way a ... [5] 
1

\section{INTRODUCTION}

Selective breeding for high growth rate and Jow feed conversion in broilers has been succesful, but selection impairs animal welfare due to health problems and behavioural changes (Savory, 2002; Bokkers and Koene, 2003; Turner et al., 2003). A modern broiler grows on average from $40 \mathrm{~g}$ to $2100 \mathrm{~g}$ in about 6 weeks. This high growth rate is different for different body parts (Nestor et al., 1985; Havenstein et al., 2003), which creates skeletal-biomechanical imbalances (Lilburn, 1994; Corr et al., 2003a, 2003b) and increases susceptibility to metabolic disorders (Scheele, 1996; Gonzales et al., 1999; Havenstein et al.,_2003):

$\underline{\text { Time spent on different behaviours has changed in fast growing broilers }}$ compared with other lines, (Bokkers et al., 2000; Bokkers and Koene, 2003), while the normal behavioural repertoire of a chicken has maintained. Incidence of several $\underline{\text { behaviour patterns decreases with increasing age and body weight. In addition, many }}$ behaviour patterns are performed increasingly in a sitting posture instead of a standing posture with increasing age, (Weeks et al., 1994; Reiter and Kutritz, 2001; Bokkers and Koene, 2003):

\section{Fast growing broilers are the most common lines kept for chicken meat} production. There are, however, slow growing lines that are also kept for chicken meat production. Roughly, there are two types of slow growing broilers: "medium" and "normal". Medium-slow growers grow to a slaughter weight of $2100 \mathrm{~g}$ in about 8 weeks whereas normal slow growers need 12 weeks to reach the same slaughter weight.

Because of their lower growth rate, slow growing broilers are presumed to have fewer health and physical problems than fast growing broilers. In the Netherlands, slow growing broilers are kept mainly for organic chicken meat production. In organic broiler production, birds are kept at a lower stocking density than in conventional broiler production. Stocking density is seen, in addition to high growth rate of the used lines, as one of the factors for welfare problems in conventional broiler production $(E U, 2000$;

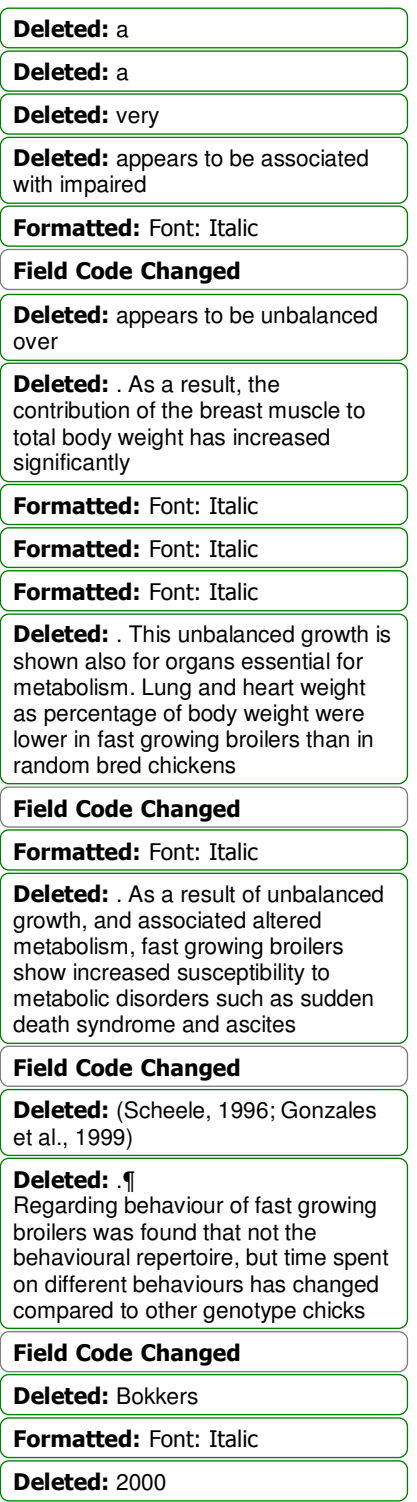

Deleted: . Several behaviour patterns decrease with increasing age and body weight and many behaviour patterns are performed in a sitting posture in stead of standing posture to an increasing extent when getting older

Field Code Changed 
Hall, 2001) A high stocking density reduces freedom of movement, and affects litter and air quality negatively (Bessei, 2006).

A decision to introduce an organic broiler production system that includes

keeping slow growing broilers at a low stocking density is expected to affect the welfare

status positively. Such a decision in favour of welfare, however, also has economic,

ecological, and other social consequences, as shown, e.g., in egg production systems

(Mollenhorst et al 2006). Organic regulations, for example, determine that animals

should have outdoor access for a certain period of their life or of the year. In addition to

improved animal welfare, such regulations may have negative environmental

consequences, such as, higher ammonia volatilisation or nitrogen leaching

(Hermansen et al., 2004). Making a well-reasoned, holistic consideration

whether one production system contributes more to sustainable development than

another, therefore, requires comparison of the economic, ecological, and social

performance of both production systems. In our case, the contribution to sustainable

development of a conventional broiler production system and an organic broiler

production system should be assessed. In this study, we compared the combined

economic, ecological, and social performance of a defined conventional broiler

production system with a defined organic broiler production system.

\section{METHODOLOGY}

The four step methodology used in this study was based on ideas of Bell and Morse

(1999), and was developed further by Mollenhorst and De Boer (1999). This

methodology has been used to evaluate the economic, ecological, and social (EES)

performance of different egg production systems, (Mollenhorst et al., 2006) and seems

suitable to evaluate the EES performance of broiler production systems. The

methodology consists of four steps: 1) description of the problem situation and

definition of the systems, 2) identification of relevant economic, ecological, and social

Formatted: Right

Deleted: (Weeks et al., 1994; Reiter and Kutritz, 2001; Bokkers and

Koene, 2003)

\section{Deleted: .}

Fast growing broilers are the most common genotypes that are kept for poultry meat production. There are, however, broilers selected especially to grow slower. Slow growing broilers are presumed to have less health and physical problems than fast growing broilers. Roughly, there are two types of slow growing broilers. Medium slow growers grow to slaughter weight in about 8 weeks while "normal" slow growers grow to slaughter weight in 12 weeks. In the Netherlands, slow growing broilers are kept mainly for organic poultry meat production. In organic broiler production birds are kept at a much lower stocking density than in conventional broiler production. Stocking density is seen as an important cause of welfare problems in conventional broiler

production, besides the unilateral genetic selection

\section{Field Code Changed}

Deleted: (EU, 2000; Hall, 2001)

Deleted: . High stocking density reduces freedom of movement, but affects also litter and air quality

Deleted: Bessei

Field Code Changed

\section{Deleted: . I}

A decision to introduce slow growing broilers in a production system and

keeping them at a low stocking

density is expected to affect the

welfare status positively. Such a

measure in favour of welfare,

however, also has economic

ecological and other societal

consequences as shown by

Mollenhorst et al.

Field Code Changed

Deleted: (2006)

Deleted: in egg production systems. Organic regulations, for example, determine that animals should $1 . .$. [8]

Field Code Changed

Deleted: (Hermansen et al., 2004)

Deleted: . Making a well reasoned

holistic consideration whether one production system contributes $\ldots$... [9]

Field Code Changed

Deleted: (2004)

Deleted: and has been further developed by Mollenhorst and De Boer

Field Code Changed

Deleted: (2004) 


\section{Step (3): Selection and quantification of indicators}

113 The third step involves the selection and quantification of indicators for the selected

114 EES issues. An indicator, which is a parameter that quantifies the status of an issue, is

issues, 3) selection and quantification of indicators for each issue, and 4) final assessment of the contribution of production systems to sustainable development.

\section{Step (1): Description of the problem situation and defining the systems}

The first step requires a description of the problem situation and definition of the

systems. The problem situation was described in the introduction. The systems were a defined conventional broiler production system and a defined organic broiler production system, each managed by one person working a full-time year (Full Time Equivalent,

FTE). Both systems were characterised by production, housing, and management, with related inputs and outputs (see below the section on definition of production systems).

\section{Step (2): Identification and definition of economic, ecological and social issues}

The second step implies the selection of EES issues relevant for sustainable

development of a broiler production system. Based on recent assessment studies

(Mollenhorst and de Boer, 2004; van Calker et al., 2004), we selected nine EES issues: profitability of the farm, acidification of the soil, eutrophication of terrestrial and aquatic ecosystems, use of fossil fuels, land use, animal welfare (including animal health), food safety, product quality and working conditions. These nine EES issues will be discussed in this study. needed for each EES issue. For the comparison of production systems, we selected

the best available indicators using six criteria: relevance, simplicity, sensitivity, reliability, trend/target, accessibility of data (Mitchell et al., 1995; de Boer and Cornelissen, 2002; Mollenhorst et al., 2006). The selected indicators for the comparison of the conventional and the organic broiler production system were quantified based on scientific literature and data bases of Dutch institutes: the

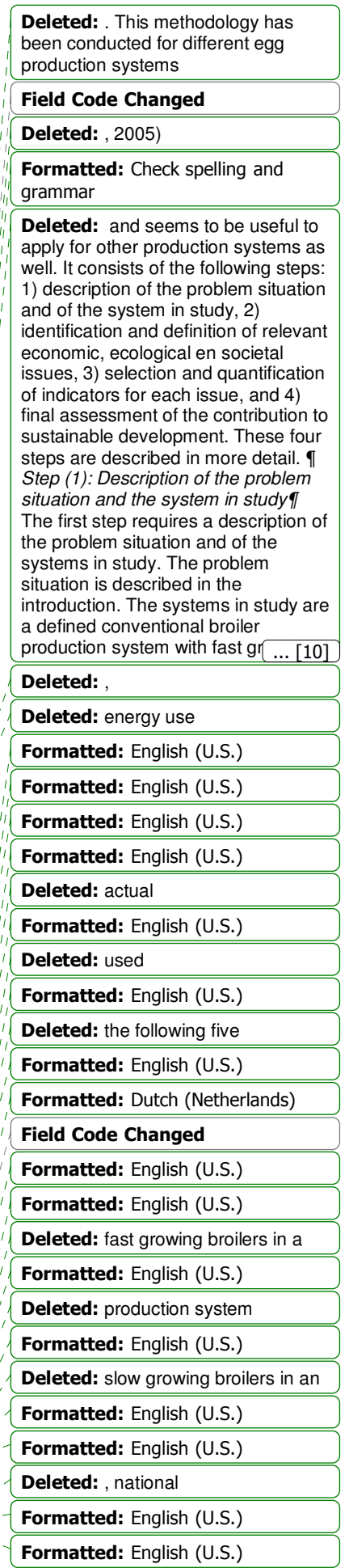



considered in the general discussion section. at a farm arrive and leave the farm at the same day.

\section{Definition of the production systems}

\section{ECONOMIC PERFORMANCE}

Net farm income is the best indicator for economic performance of a farm (van Calker et al., 2005). Net farm income is defined as the difference between revenues and costs, excluding costs of family labour (van den Tempel and Giesen, 1992). To

estimate economic performance, we must first describe the system and the year in which the computations were pased. A conventional broiler production system (further called conventional system) was compared with an organic broiler production system (further called organic system), both managed by one FTE in 2003. For this study it was assumed that both systems use an all-jn all-out procedure to start and finish a production round. An all-in all-out procedure means all birds within a production round

Deleted: RESULTS AND

DISCUSSION Economic issues?

Deleted: system

Field Code Changed

Formatted: Font: Italic

Deleted: must

\begin{tabular}{|l|}
\hline Deleted: on \\
\hline Deleted: are \\
Deleted: system with fast growing \\
broilers \\
\hline Deleted: in this paragraph) is \\
\hline Deleted: system with slow growing \\
broilers \\
\hline Deleted: in this paragraph \\
\hline Deleted: fulltime equivalent ( \\
\hline Deleted: ) \\
\hline Deleted: in the year \\
\hline Deleted: is presumed \\
\hline Deleted: production \\
\hline Deleted: \\
\hline Deleted: \\
\hline
\end{tabular}


Data and assumptions for economic calculations

\section{INSERT TABLE 1}

Formatted: Indent: First line: $0 \mathrm{pt}$
Deleted: . Birds are kept with a
stocking
Deleted: of
Deleted: and a
Deleted: period
Deleted: $365 / 53=6.9$
Deleted: . The birds are housed
under conditions of artificial light.
Climate in the house is
Deleted: in

Deleted: it is allowed to keep

Deleted: at maximum

\begin{tabular}{l} 
Deleted: So, one FTE is allowed to \\
manage 16,000 birds that have to be \\
kept in several houses. \\
\hline Deleted: genotypes \\
Deleted: In \\
\hline Deleted: this means that \\
geleted: because the only used \\
genotypes \\
\hline Deleted: enlightened with \\
Deleted: and additional \\
Deleted: the \\
\hline Deleted: Water \\
\hline Deleted: which \\
\hline Deleted: of \\
\hline \\
\hline
\end{tabular}


172
173 needed to be taken into account.
For the conventional system, calculation of net farm income was based on intensive animal production in the Netherlands (KWIN, 2003-2004; 2006), whereas for the organic system calculation of net farm income was based on data of Vermeij (2004)

(Table 2). Vermeij (2004) made several assumptions for the organic system because data were lacking. These assumptions are summarised, Water intake is related to feed in a ration of 1.8:1. Water intake of a broiler was 7 I in 43 days, so water intake was assumed to be $11.5 \mathrm{I}$ in 70 days. Costs for health care were expected to be higher for an organic system than for a conventional system because extra vaccinations are necessary due to outdoor access. Costs per bird for electricity were expected to be lower than in a conventional system due to natural ventilation and natural daylight. a

Although a similar amount of energy is used in both systems to heat one $\mathrm{m}^{3}$ of air, heating costs per bird were expected to be higher in an organic system than in a conventional system. This difference was expected because in an organic system fewer birds are kept per $\mathrm{m}^{2}$, which makes it more expensive to heat the building when expressing the costs per bird. Costs per bird for bedding were higher in an organic than in a conventional system, because more litter is used per square meter and birds are kept in a lower stocking density. Costs for catching and loading the birds for slaughter were higher for an organic system due to smaller flocks. Costs for legal animal health levies collection service for dead animals were similar for both systems. Manure transport for the conventional system was based upon a farm with no land. Because there is a manure surplus in the Netherlands, the removal of manure from the farm involves costs. This situation is different for an organic system. There was enough demand for organic poultry manure that no costs for manure removal and transport

196 Final economic calculations
Formatted: Indent: First line: 0 pt
Deleted: a reference book full quantitative information

\begin{tabular}{|c|}
\hline $\begin{array}{l}\text { Deleted: was used as base for the } \\
\text { conventional system and }\end{array}$ \\
\hline $\begin{array}{l}\text { Deleted: as base for the organic } \\
\text { system }\end{array}$ \\
\hline $\begin{array}{l}\text { Deleted: broiler production because } \\
\text { actual data did and do not exist }\end{array}$ \\
\hline Deleted: relates \\
\hline Deleted: as \\
\hline Deleted: is \\
\hline Deleted: , \\
\hline Deleted: is \\
\hline $\begin{array}{l}\text { Deleted: According to Vermeij } \\
\text { (2004) costs }\end{array}$ \\
\hline Deleted: are \\
\hline Deleted: broiler \\
\hline Deleted: are \\
\hline Deleted: per bird \\
\hline $\begin{array}{l}\text { Deleted: making use of day light. } \\
\text { Heating costs are expected to be } \\
\text { higher per bird in the organic system } \\
\text { because a }\end{array}$ \\
\hline $\begin{array}{l}\text { Deleted: but in the production } \\
\text { system with the slow growing broilers } \\
\text { it is divided by }\end{array}$ \\
\hline $\begin{array}{l}\text { Deleted: per square meter due to a } \\
\text { lower stocking density. Costs for }\end{array}$ \\
\hline Deleted: are \\
\hline $\begin{array}{l}\text { Deleted: per bird in organic slow } \\
\text { growing production }\end{array}$ \\
\hline Deleted: are a little \\
\hline Deleted: per bird \\
\hline Deleted: the \\
\hline Deleted: and carrion collecting \\
\hline Deleted: are \\
\hline Deleted: production \\
\hline Deleted: No \\
\hline Deleted: were \\
\hline $\begin{array}{l}\text { Deleted: for the organic system } \\
\text { because there is enough demand for } \\
\text { organic poultry manure to find a } \\
\text { destination without costs }\end{array}$ \\
\hline
\end{tabular}

Deleted: was used as base for the

Deleted: as base for the organic

Deleted: broiler production because actual data did and do not exist

Deleted: relates

Deleted: (2004) costs

Deleted: broile

Deleted: are

Deleted: per bird

Deleted: making use of day light.

Heating costs are expected to be because a

Deleted: but in the production system with the slow growing broilers

Deleted: per square meter due to a r stocking density. Costs for

Deleted: per bird in organic slow growing production

Deleted: the

Deleted: are

Deleted: production

organic poultry manure to find 
Final economic calculations are summarised in Table 3. Regarding the variable to be similar for both systems.

\section{INSERT TABLE 3}

For the conventional system, investment costs were estimated 180 EUR per $\mathrm{m}^{2}$ for the building and 70 EUR per $\mathrm{m}^{2}$ for the inventory (KWIN, 2003-2004). For the organic system, investment costs were estimated 160 EUR per $\mathrm{m}^{2}$ for the building and 30 EUR per $\mathrm{m}^{2}$ for the inventory (Vermeij, 2004).

For the conventional system, depreciation for the building was $3.5 \%$ and for the organic system, it was $3 \%$. Maintenance costs for the building were $1 \%$ for both systems. Costs for depreciation (6.5\%) and maintenance (2\%) for the inventory were similar for both systems (KWIN, 2003-2004).

Investments for the outdoor run in the organic system were 37,400 EUR per ha.

Costs for the outdoor run were based on interest $\left(0.09\right.$ EUR per $\left.\mathrm{m}^{2}\right)$, costs for fencing and furniture $\left(0.025\right.$ EUR per $\left.m^{2}\right)$, and maintenance $\left(0.02\right.$ EUR per $\left.m^{2}\right)$ (Vermeij, 2004). Organic production has to answer to special regulations that are controlled by the independent organisation "Skal" in the Netherlands. Levies for Skal were based on an annual fee of 260 EUR and an additional 0.05 EUR per bird (Skal, 2004). Finally, costs for accounting, insurances, telephone, clothing, contributions, etc, were, expected

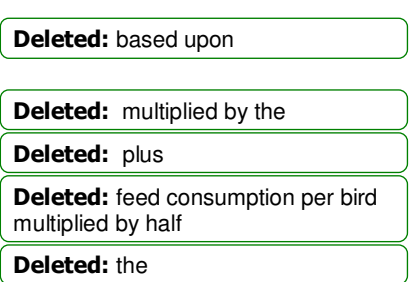

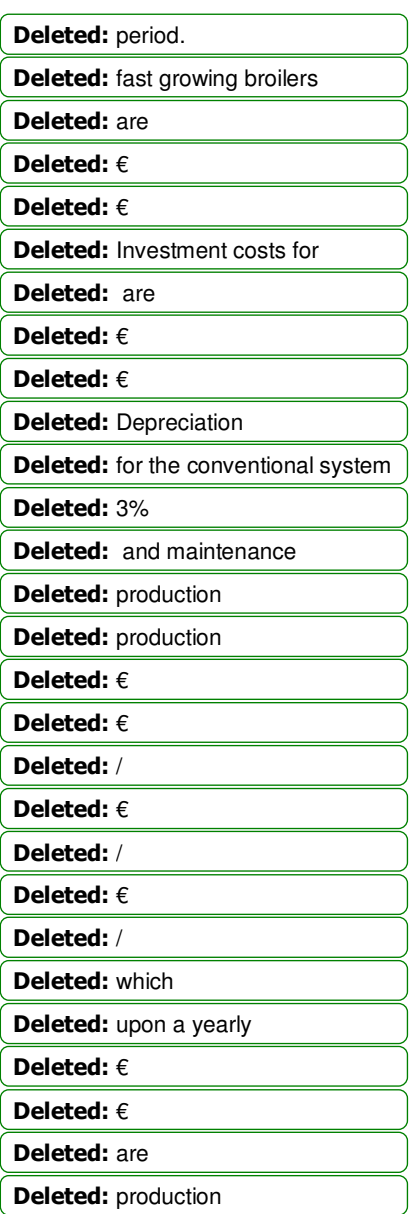


222 Although price per kg of meat was lower for the conventional system than for the

organic system, total revenues were higher because of more birds per production round $(70,000$ vs 16,000$)$ and more production rounds per year (6.9 vs 4.6$)$. More birds and production rounds, however, also meant more total costs (689 vs 265 kEUR). The main contributors to the higher costs in the conventional system were feed (399 vs 165

kEUR) depreciation (45 vs 14 kEUR), and manure transport (12 vs 0 kEUR). As a result net farm income was higher in the organic system (73 kEUR) than in the conventional system (7 kEUR). Economic results, however, depend heavily on market prices and feed costs. In the future, for example, when the consumer market for organic broiler meat increases, production will increase as well. The whole production chain will get more professional and therefore more efficient. Consequently, prices and costs will decrease. It is difficult to predict whether an organic broiler farmer can make a profit in that case.

Economic calculations were based on several assumptions. One assumption was that all parts of the organic birds were sold as organic meat. In reality, however, it is hard to sell all parts as organic meat, especially in the Netherlands, where many consumers buy only specific fresh chicken parts, such as breasts and legs instead of a whole chicken. The market for other fresh chicken parts is variable in the Netherlands. Unsold parts will be processed by the food industry or exported, in many cases as conventional meat ${ }_{2}$ which reduces profits for the farmer. Furthermore, the market for organic products is small. High prices for organic meat compared with conventional, meat and limited availability in supermarkets account for the limited demand by consumers for organic products (Tacken et al.,. 2007).

In addition, the farm size for the organic system js large compared with the average farm size, which is around 3,200 birds per farm. Consequently most farmers with an organic system need to have a second source of income. The low net farm income of the conventional system corresponded to reality, because conventional,
Deleted: As shown

Deleted: table 3,

Deleted: production system Calculations are

Deleted: important

Deleted: of these birds Deleted: . Especially

Deleted: most
Deleted: to conventional chicken

Deleted: are mentioned in relation to

\begin{tabular}{|l|}
\hline Deleted: of \\
\hline Field Code Changed \\
\hline Formatted: Font: Italic \\
\hline Deleted: assumed \\
\hline Deleted: assumed \\
\hline Deleted: broiler production \\
\hline Deleted: to \\
\hline Deleted: organic broiler \\
\hline
\end{tabular}


broiler production has not been very profitable in the Netherlands recent years (Bolhuis and Wisman, 2007).

\section{ECOLOGICAL PERFORMANCE}

The environmental performance of a broiler production system can be quantified by

assessing the impact of that system on acidification of the soil, eutrophication of

terrestrial and aquatic ecosystems, and on climate change, and by measuring its use of

land and fossil fuels (de Boer, 2003). There are more issues related to ecological

performance, such as human toxicity, terrestrial and aquatic eco-toxicity, biodiversity,

$\underline{\text { soil quality, and water use that are affect by a production system. These issues, }}$

however, were not addressed in this study, because there is no generally accepted and

validated assessment method or because required data were not available

\section{(Thomassen, 2008).}

\section{Acidification and eutrophication}

262 The computation in this section could not be based upon the technical data as given in

Table 1, because relevant data were lacking. Computations were done for the conventional system and the organic system, in which broilers reach slaughter weight in 43 days and 81 days, respectively,

Ammonia $\left(\mathrm{NH}_{3}\right)$ emission from animal manure is a major contributor to

acidification (Groot Koerkamp, 1994). The $\mathrm{NH}_{3}$ emission per kg live weight, therefore, js a relevant indicator for acidification (Thomassen and de Boer, 2005). Conventional broilers on litter emitted on average $11.2 \mathrm{mg}$ per $\mathrm{h}_{3}$ which is $0.08 \mathrm{~kg} \mathrm{NH}_{3}$ per bird place per year $\left(0.08 \mathrm{~kg}=11.2 \mathrm{mg} / \mathrm{h} / \mathrm{bird} \mathrm{x}_{2} 24 \mathrm{~h} \mathrm{x}_{\mathbf{w}}(365 / 53)\right.$ rounds $\mathrm{x}, 43$ days of life) $/ 1,000,000)$ (Groot Koerkamp et al., 1998). This value is used as the emission factor for broilers in the Netherlands (VROM, 2002). Assuming a live weight of $2.1 \mathrm{~kg}$ per bird, $5.5 \mathrm{~g} \mathrm{NH}_{3}$ volatilises per $\mathrm{kg}$ of live weight annually. For an organic system the $\mathrm{NH}_{3}$ emission per bird place per year is unknown. A conventional broiler

Deleted: meat Deleted: last

Deleted: Our results found for economic performance correspond, therefore, to reality.

Deleted: Ecological issues $\mathbb{1}$

Deleted: , global warming and to determine

Deleted:

Deleted: paragraph

Deleted: table

Deleted: fast growing

Deleted: grown to

Deleted: for slow growing broilers in 81 days

\begin{tabular}{|l|}
\hline Deleted: , and, \\
\hline Deleted: bird produced \\
\hline $\begin{array}{l}\text { Deleted: Groot Koerkamp et al. } \\
\text { (1998) found that a conventional } \\
\text { broiler }\end{array}$ \\
\hline Deleted: our \\
\hline Deleted: /day $\times$ \\
\hline Deleted: $\times$ \\
\hline Deleted: $\times$ \\
\hline Deleted: ). \\
\hline Deleted: laid down \\
\hline Deleted: Dutch directive "Ammonia \\
and animal husbandry" \\
\hline Deleted: life \\
\hline Deleted: bird \\
\hline Deleted: broiler \\
\hline Deleted: We \\
\hline
\end{tabular}


produces $1.275 \mathrm{~kg}$ manure in 43 days (Oenema et al., 2000), whereas an organic broiler produces $3.4 \mathrm{~kg}$ per bird in 81 days (Gordon and Charles, 2002). Annually,

therefore, a conventional broiler produces $8.8 \mathrm{~kg}$ of manure $(1.275 \times 365 / 53)$, whereas an organic broiler produces $13.6 \mathrm{~kg}(3.4 \times 365 / 91)$. In addition, a conventional broiler excretes $0.543 \mathrm{~kg} \mathrm{~N}$ per bird place per year (Groenestein et al., 2005), which converts

to $6.1 \%$ of total manure production. An organic broiler excretes $0.843 \mathrm{~kg} \mathrm{~N}$ per year, assuming a similar $\mathrm{N}$ percentage in manure.

The $\mathrm{NH}_{3}$ emission of a conventional proiler was $0.08 \mathrm{~kg} \mathrm{NH} 3$ per bird place per

year, or $0.066 \mathrm{~kg} \mathrm{~N}$. Assuming a similar $\mathrm{NH}_{3}$ emission factor of $12.1 \%(100 \mathrm{x}$

$\underline{0.066 / 0.543)}$ the $\mathrm{NH}_{3}$ emission of an organic broiler is $0.10 \mathrm{~kg} \mathrm{~N}$ per bird place per year, Based on a live weight of $3.050 \mathrm{~kg}$ at 81 days, $8.3 \mathrm{~g} \mathrm{NH}$ volatilizes per $\mathrm{kg}$ of live

weight annually. Hence, annual $\mathrm{NH}_{3}$ emission per $\mathrm{kg}$ of live weight js $51 \%$ higher for an organic system than for a conventional system.

The previous, computation was based on the assumption that the $\mathrm{N}$ content of manure ${ }_{2}$ and its related $\mathrm{NH}_{3}$ emission factor, were equivalent for conventional and organic systems. The $\mathrm{N}$ content of manure depends mainly on the composition of the feed, and composition of the feed does not need to be different between the conventional and the organic system. The $\mathrm{NH}_{3}$ emission factor, however, depends on the housing system, stocking density, air temperature and velocity, and $\mathrm{pH}$ of manure (Groot Koerkamp, 1994). No information is available, however, to quantify the influence of these factors on $\mathrm{NH}_{3}$ emission.

Organic broilers must have an outdoor run for at least one third of their life (EU, 1999), which might also influence the $\mathrm{NH}_{3}$ emission factor. Emission of $\mathrm{NH}_{3}$ in the outdoor run depends on the time broilers spend outside, which itself depends on conditions, such as weather, season, temperature, facilities ${ }_{2}$ and experience of the broilers. The influence of an outdoor run on $\mathrm{NH}_{3}$ emission is unknown, and requires further research. Besides its contribution to acidification, an outdoor run carries a risk to ecology regarding eutrophication through leaching of excess of nitrate and phosphate.

Formatted: Right

\begin{tabular}{|c|}
\hline $\begin{array}{l}\text { Deleted: do know that a fast growing } \\
\text { broiler }\end{array}$ \\
\hline Formatted: Font: Italic \\
\hline Deleted: a slow growing \\
\hline Field Code Changed \\
\hline $\begin{array}{l}\text { Deleted: a fast growing broiler, } \\
\text { therefore, }\end{array}$ \\
\hline Deleted: a slow growing \\
\hline Deleted: fast growing \\
\hline Field Code Changed \\
\hline Formatted: Font: Italic \\
\hline Deleted: (i.e., \\
\hline $\begin{array}{l}\text { Deleted: ). Assuming a similar } \mathrm{N} \\
\text { percentage in manure, a slow } \\
\text { growing }\end{array}$ \\
\hline $\begin{array}{l}\text { Deleted: . The } \mathrm{NH}_{3} \text { emission per bird } \\
\text { place per year of a fast growing }\end{array}$ \\
\hline Deleted: , i.e., \\
\hline Deleted: \%, \\
\hline Deleted: is $0.10 \mathrm{~kg} \mathrm{~N}$ \\
\hline Deleted: life \\
\hline Deleted: bird \\
\hline Deleted: bird \\
\hline Deleted: produced \\
\hline Deleted: production. \\
\hline Deleted: above described \\
\hline Deleted: is \\
\hline Deleted: are \\
\hline Deleted: fast \\
\hline Deleted: slow growing broilers \\
\hline $\begin{array}{l}\text { Deleted: . The } \mathrm{N} \text { content of the diet } \\
\text { between fast and slow growing } \\
\text { broilers }\end{array}$ \\
\hline
\end{tabular}

Deleted: The total living space and stocking density, for example, which differ between fast and slow growing broilers, might influence the $\mathrm{NH}_{3}$ emission factor (Groot Koerkamp, 1994). At this moment, however, no

Deleted: In addition, the fact that organic birds spend time in the outdoor run influences the $\mathrm{NH}_{3}$ emission factor.

Deleted: highly

Deleted: , e.g., weather

Deleted: currently 
It was found that 3,000 laying hens that could be outdoor from 11:00 $\mathrm{h}$ till sunset at an organic commercial farm produced on average $2,845 \mathrm{~kg} \mathrm{~N}$ per ha per year (Aarnink $\mathrm{et}$ al., 2006), which is higher than the legal limit of $170 \mathrm{~kg} \mathrm{~N}$ per ha per year (EU, 1991).

Furthermore, a large part of this manure was dropped close to the hen house, resulting in an even increased risk for eutrophication. № such data exist for broilers with an outdoor run, but it is clear that there is a risk for eutrophication in organic broilers.

\section{Fossil-fuel use and climate change}

Regarding use of fossil fuels, we distinguished between direct and indirect $\mu$ se. Direct use includes, use of oil, gas ${ }_{2}$ and electricity on the broiler farm, whereas indirect use includes use of fossil fuels for production and transport of farm inputs, such as, concentrates. In a conventional system, $25 \%$ of the total use of fossil fuels is, direct use of electricity and gas at the farm, whereas $70 \%$ is , indirect use for cultivation and transport of concentrates (Spedding et al., 1983; Vermeij, 2004). In a conventional system, direct use is electricity for mechanical ventilation and for lightning of the stable, on average about $0.15 \mathrm{kWh}$ per bird per day (Dyer and Desjardins, 2006). In an organic system, natural ventilation is used and artificial light is used only in winter (Rodenburg and van Harn, 2004). Therefore, electricity use was estimated to be $50 \%$ lower for an organic compared with a conventional system (Vermeij, 2004). In addition to electricity, a conventional system uses, on average $0.09 \mathrm{~m}^{3}$ gas for heating during the first 3 weeks of production to maintain the body temperature of young chicks (Vermeij, 2004). In an organic system, however, the amount of fossil fuels required for heating is expected to double due to the lower stocking densities, (Vermeij, 2004).

Overall, the direct use of fossil fuels is expected to be $25 \%$ higher for an organic system compared with a, conventional system (Vermeij, 2004). Indirect use for fossil fuels, required for the cultivation and transport of feed ingredients account for around $70 \%$ of the total use of fossil fuels. Concentrate composition and feed conversion, therefore, are useful measures, for indirect use of

Deleted: 000 layers at an organic commercial farm

Formatted: Font: Italic Field Code Changed

Deleted: much .... In addition...is very ...hens'...higher ...As far as we

know no ... [11]

Deleted: energy

Deleted: global warming

energy use, we distinguish ...fossil energy ....fossil energy

comprises...energy ...comprises...the like...production...energy use comprises...energy .... of the total energy comprises...fossil energy required for the production 


\section{$354 \quad$ Land use}

355 Land use (on and off-farm) in broiler production is reported to be $5.0 \mathrm{~m}^{2}$ per $\mathrm{kg}$ of meat

fossil fuels. Feed conversion ( $\mathrm{kg}$ feed/kg gain) is 1.76 for the conventional system and 2.45 for the organic system (KWIN, 2003-2004; Vermeij, 2004). Indirect use of fossil fuels is expected to be higher in an organic system compared with a conventional system, due to this higher feed conversion. This expected increase, however, might be partly compensated for with lower use of fossil fuels for transport of feed ingredients due to the use of locally grown feed. Overall, total energy use per kg of live weight varies in literature between 8.4-17 MJ for conventional production, Ellendorff, 2002;

Williams et al., 2006; Blonk et al., 2007). For organic production, total energy use per

kg of live weight is estimated to be 30-59\% higher (Ellendorff, 2002; Williams et al., 2006; Blonk et al., 2007).

Worldwide, the main green houses gasses (i.e gasses that contribute to climate change), related to animal production are carbon dioxide $\left(\mathrm{CO}_{2}\right)$, methane $\left(\mathrm{CH}_{4}\right)_{2}$ and nitrous oxide $\left(\mathrm{N}_{2} \mathrm{O}\right)$ (de Boer, 2003). Emission of $\mathrm{CO}_{2}$ is related to combustion of fossil fuels and deforestation. Methane emission in broiler production results from manure only. Enteric methane emission from poultry is assumed to be negligible (IPCC, 2006). Nitrous oxide emission results mainly from application of fertilizer during $\underline{\text { cultivation of feed ingredients. For conventional production, emission of green house }}$ gases per one $\mathrm{kg}$ of live weight of chicken is estimated at $2-3.2 \mathrm{~kg}$ expressed in $\mathrm{CO}_{2}$ units (IPCC, 2006; Williams et al., 2006). These estimates include green house gas emissions on the broiler farm and emissions during the production of transport of farm inputs, such as concentrates (i.e. off-farm emissions). For organic production, emission of green house gases is estimated to be $50 \%$ higher (Williams et al., 2006). The lower feed conversion and use of organic feed explain the higher emission of green house gases in organic production, jn a conventional system (Blonk et al., 2007). For organic production, land use, is
Deleted: energy use

Deleted: equals

Deleted: production

Deleted: energy

Deleted: to

Deleted: production

Deleted: the

Deleted: Unless, this is

Deleted: energy

Deleted: Ellendorf et al.

Field Code Changed

Deleted: global warming than a conventional produced indirect fossil energy use it

Deleted: suggested that a organic produced broiler contributes more 
357 estimated to be 92-119\% higher (Williams et al., 2006; Blonk et al., 2007). This,

difference between the conventional and organic system is because were fed organic feed. The harvest per hectare of organically grown crops is generally, lower than that of conventionally grown crops. Hence, more land is used to produce for $1 \mathrm{~kg}$ of feed in an organic system than in a conventional system. Another factor that might influence Jand use per $\mathrm{kg}$ of broiler meat is the feed conversion, which is higher in organic than in conventional broilers. The more feed that is needed to produce $1 \mathrm{~kg}$ of meat, the more land is needed for the production of feed.

\section{SOCIAL PERFORMANCE}

Animal welfare

The Farm Animal Welfare Council (1992), formulated five freedoms that define ideal states for animal welfare: 1) freedom from hunger and thirst; 2) freedom from

discomfort; 3) freedom from pain, injury or disease; 4) freedom to express normal behavior; 5) freedom from fear and distress. Mollenhorst et al. (2006) showed that behavioural studies provide relevant indicators regarding not only freedom to express normal behaviour, but also freedom from discomfort, fear, and distress. In addition, to assess freedom from pain, injury or disease, indicators such as disease incidence or clinical observations appear relevant. From literature, we deduced the following five indicators for animal welfare in broilers: time spent on walking, percentage of birds with footpad lesions, gait score, percentage of birds with heart abnormalities, and mortality rate. Because behavioural and animal health studies with slow growing broilers are not always conducted within the constraints of organic production, it will be mentioned in this section whenever a study was done within the organic constraints. Time spent on walking is used to judge physical abilities and capacities of a broiler Slow growing broilers spent twice as much time on walking than fast growing

\begin{tabular}{|l|}
\hline Deleted: are \\
\hline Deleted: with \\
\hline Deleted: organic \\
\hline Deleted: in general \\
\hline Deleted: feed production \\
\hline Deleted: which may \\
\hline Deleted: the \\
\hline
\end{tabular}

Deleted: Social issuesq

Formatted: English (U.S.) Formatted: Dutch (Netherlands) Formatted: English (U.S.)

Deleted: cover the animal's basic needs.

Formatted: Font: Italic

Deleted: To

Deleted: foot pad disorders Deleted: hearth

\begin{tabular}{l}
\hline Deleted: Walking behaviour \\
Deleted: a parameter that is \\
\hline Deleted: in several studies \\
\hline Deleted: bird
\end{tabular}


5

broilers at 6 weeks of age (Weeks, 2002). At 5 weeks of age, slow growers walked

$4.4 \%$ of their time, whereas fast growers walked $1.5 \%$ of the time, both housed with a stocking density of 20 birds per $\mathrm{m}^{2}$ (Reiter and Kutritz, 2001). This finding is in accordance with results of Bokkers and Koene (2003), who kept broilers in a lower stocking density ( 4 birds per $\mathrm{m}^{2}$ ) and found that slow growers walked $6.7 \%$ of the observed time at 6 weeks of age, whereas fast growers walked 2.0\%. Percentage, walking decreased to $5.8 \%$ in slow growers and to $1.2 \%$ in fast growers at 12 weeks of age. Time spent on walking is low in both fast and slow growers compared with chicks of a layer line (13.4\% at 6 weeks of age) (Bokkers, not published).

Gait score is, another way to study walking behaviour. Gait score has a six point scale: from $0=$ no detectable walking abnormalities to $5=$ incapable of sustained walking on its feet (Kestin et al., 1992). A high gait score, therefore, means worse walking behaviour and consequently an indicator for jmpaired welfare. Average gait score was 0.25 for slow growering and 2.18 for fast growing female broilers at 78 days of age (Nielsen et al., 2003). One percent of the slow growing line and $87 \%$ of the fast growing line, had a gait score higher than 1 at that age (Nielsen et al.,2003). Fast. growing lines, had a gait score of 2.9 at 54 days of age and 3.8 at 81 days, whereas, slow growing lines, had a gait score of 1.5 at 54 days of age and 2.0 at 81 days (Kestin et al., 2001), Based on walking behaviour and gait scores, therefore, we concluded that walking performance was better in slow growing broilers than in fast growing broilers.

Fast growing broilers seemed to be physically restricted but the motivation to walk was still present (Bokkers et al., 2007), which can be interpreted as a situation of reduced welfare.

\section{housing conditions, such as moisture and chemical irritants in the litter, were} associated with footpad lesions (Ekstrand et al.., 1998). Stocking density activity of the birds, and location in the house affected litter quality (Gordon, 1992; Su et al., 2000; Tasistro et al., 2004). Footpad lesions were found in $75.5 \%$ of fast growers and $1.5 \%$ in

Deleted: Reiter and Kutritz (2001) found that

Deleted: at 5 weeks of age while

Deleted:

\begin{tabular}{|c|}
\hline Deleted: / \\
\hline $\begin{array}{l}\text { Deleted: in their experiment. They } \\
\text { showed }\end{array}$ \\
\hline Deleted: and fast growers $2.0 \%$ \\
\hline Deleted: . In both genotypes ... [15] \\
\hline Deleted: respectively of the $\ldots[16]$ \\
\hline Deleted: Compared to chicks ... [17] \\
\hline Deleted: . Layer \\
\hline Deleted: spent \\
\hline Deleted: of their time on wall $\ldots[18]$ \\
\hline Deleted: (Arens, 2000). In \\
\hline Deleted: experimental settin $\_$... [19] \\
\hline Deleted: capacities of broiler ... [20] \\
\hline Deleted: , \\
\hline Field Code Changed \\
\hline Formatted: Font: Italic \\
\hline Deleted: The higher the scor $\ldots[21]$ \\
\hline Deleted: . The overall \\
\hline Deleted: growing \\
\hline Field Code Changed \\
\hline Formatted: Font: Italic \\
\hline Deleted: genotype \\
\hline Deleted: genotype \\
\hline Field Code Changed \\
\hline Formatted: Font: Italic \\
\hline Deleted: Kestin et al. (2001) ... [22] \\
\hline Deleted: genotypes \\
\hline Deleted: of age, while \\
\hline Deleted: genotypes \\
\hline Deleted: 54 respectively \\
\hline Deleted: of age \\
\hline Deleted: up \\
\hline Deleted: it can be \\
\hline Deleted: is \\
\hline Deleted: is \\
\hline Field Code Changed \\
\hline Formatted: Font: Italic \\
\hline Deleted: Foot pad lesions ar ... [23] \\
\hline Formatted: Font: Italic \\
\hline Deleted: Foot pad lesions aff ... [24] \\
\hline Deleted: and genotype affec ... [25] \\
\hline Deleted: is therefore a usefu $\ldots[26]$ \\
\hline
\end{tabular}


slow growers at 84 days of age (Nielsen et al., 2003). In addition $78.3 \%$ of fast

growers had footpad lesions at 40.5 days of age compared with, $5.4 \%$ of medium-slow growers, at 50 days, (van Horne et al., 2003). In the UK, $14.8 \%$ of conventional, reared fast growing broilers had footpad lesions, at 39 days of age, whereas, $9.6 \%$ of mediumslow growing broilers, had lesions at 49 days (Pagazaurtundua and Warriss, 2006).

Rodenburg et al. (2004) found more footpad lesions in fast growing (88.5\% at 41 days

of age) and medium-slow growing ( $16 \%$ at 55 days of age) broilers with a roofed

outdoor run than in fast growing (83.5\% at 41 days of age) and medium-slow growing

( $11.5 \%$ at 55 days of age) broilers that were kept indoors, In both situations, the fast

growing broilers had a higher prevalence than the medium-slow growing broilers.

In an organic broiler production system a prevalence of footpad lesions of

$98.1 \%$ was found at 70 days of age (Pagazaurtundua and Warriss, 2006). A higher age and the outdoor run were associated with this high prevalence of footpad lesions. So, it appeared, that results of different studies are contradictorily because footpad lesions appeared, more frequently in fast growing broilers, but an outdoor run = as compelled in

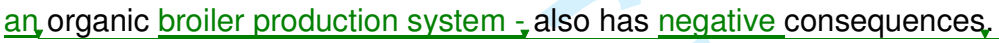

Heart abnormalities, in broilers are associated with growth and ${ }_{2}$ therefore, are, $a$ useful indicator for welfare, Heart abnormalities were found, more frequently in fast growers $(22.0 \%)$ than in slow growers $(4.3 \%)$ at 12 weeks of age (Bokkers and Koene, 2003). Mortality due to cardiovascular disorders was higher in fast growers, $(2.1 \%) \mathrm{kept}$ until 42 days of age than in medium-slow growers, $(0.4 \%)$ kept until 56 days of age (van Horne et al., 2003).

In animal production, mortality is the ultimate consequence of a failing biological-adaptation mechanism. Mortality therefore, is an indirect or cumulative animal welfare indicator. Mortality rate at commercial farms averages $4 \%$ for conventional systems, after 43 days (KWIN, 2006) and $3 \%$ for organic systems, after 70 days (Tacken et al., 2003; Vermeij, 2004). In two experiments, mortality rate for fast growers averaged $4.8 \%$ at 42 days of age and for medium-slow growers averaged 
$4391.5 \%$ at 56 days of age (van Horne et al.,2003). Cause of death, such as heart failure,

440 is not well documented, in contrast to the number of deaths.

\section{Food safety}

442 Food safety refers to substances or organisms that unintentionally contaminate food

443 and that are a health risk to the consumer. Broiler products mainly hold the risk of

\section{Salmonella spp.}

Using antibiotics in animal production results in a high risk of organisms developing resistance to antibiotics, especially when these organisms are infectious for animals and humans. Resistance may occur when medicines such as tetracyclines and quinolones are used in animals and humans (Kramer et al., 2003). In a Dutch study, residues of antibiotics were found in $8.3 \%$ proiler product samples of a conventional system, whereas there were found in $0 \%$ broiler products samples of an organic system (Kramer et al., 2003). None of the samples exceeded the legal maximum residue level as laid down by the European Union,(Kramer et al., 2003), Samples of broiler products of both conventional and organic systems contained bacteria strains with resistance to several antibiotics, (van der Zee et al., 2005). Samples of conventional system broiler products, however, showed a higher resistance and a resistance to more antibiotics than samples of an organic system, (van der Zee et al.., 2005), It seems, therefore, that meat from an organic system contains fewer residues of antibiotics and has less antibiotic resistant micro-organisms than from a conventional system.

\section{of bacterial diarrhoeal disease worldwide. (Humphrey, 2006). Broiler meat is}

considered one of the most important sources of Campylobacter spp. infection for humans (Altekruse et al., 1994). Measurements to detect sources of risk can be $\underline{\text { conducted not only at farms, but also at broiler product outlets to assess the direct risk }}$

\begin{tabular}{|l|}
\hline Deleted: like \\
\hline Field Code Changed \\
\hline Formatted: Font: Italic \\
\hline Deleted: very \\
Deleted: Total mortality therefore is \\
a good indicator but detailed data are \\
needed to be able to quantify this \\
issue properly. \\
\hline Deleted: are unintentional \\
contaminating \\
\hline Deleted: which do cause \\
\hline
\end{tabular}

\begin{tabular}{|c|}
\hline Deleted: There is \\
\hline Deleted: against \\
\hline $\begin{array}{l}\text { Deleted: when using many } \\
\text { antibiotics in animal production }\end{array}$ \\
\hline $\begin{array}{l}\text { Deleted: are used both in human } \\
\text { and animals }\end{array}$ \\
\hline Field Code Changed \\
\hline Formatted: Font: Italic \\
\hline Deleted: of conventional \\
\hline Deleted: while this was $0 \%$ \\
\hline Deleted: organic \\
\hline Field Code Changed \\
\hline Formatted: Font: Italic \\
\hline Deleted: . Van der Zee et al. \\
\hline Field Code Changed \\
\hline Deleted: (2005) \\
\hline Deleted: found that samples \\
\hline Deleted: Dutch \\
\hline Deleted: broiler products \\
\hline Deleted: against \\
\hline $\begin{array}{l}\text { Deleted: . Samples of conventional } \\
\text { broilers showed however resistance } \\
\text { against more antibiotics. In case } \\
\text { resistance against a antibiotic was } \\
\text { found in samples of both production } \\
\text { systems, samples of the conventional } \\
\text { production method had a high ... [34] }\end{array}$ \\
\hline Formatted: Font: Italic \\
\hline Deleted: . Although based uf ... [35] \\
\hline Field Code Changed \\
\hline Deleted: (Humphrey, 2006) \\
\hline Deleted: . Broiler meat is $\ldots[36]$ \\
\hline Field Code Changed \\
\hline Deleted: (Altekruse et al., 1994) \\
\hline Deleted: . Measurements car ... [37] \\
\hline Field Code Changed \\
\hline Deleted: van der Zee \\
\hline Formatted: Font: Italic \\
\hline Deleted: 2005) \\
\hline
\end{tabular}


for consumers. The percentage of samples of fresh chicken products bought from supermarkets, poulterers, and butchers across the Netherlands and over 2003-2004. that were contaminated with Campylobacter spp. averaged $27.6 \%$ for a conventional system and 40.1 for an organic system, van der Zee et al., 2005). In another Dutch

$\underline{\text { study, there was no difference between Campylobacter presence in products of a }}$

conventional system (43\%) and an organic system (49\%) (Kramer et al., 2003)

Campylobacter presence at slaughter was $36.7 \%$ in birds of a conventional system and

$100 \%$ in birds from an organic system, (Heuer et al., 2001), indicating a high risk for the meat to be contaminated at slaughter, especially organic broiler meat.

Salmonella spp. are a second group of zoonotic pathogens for which broiler meat is a major cause of infections. Humphrey, 2006), and meat from conventional systems tend to be contaminated more often. The percentage of samples of fresh broiler products taken over a whole year that were contaminated with Salmonella spp. averaged $9.3 \%$ for a conventional system and $2.8 \%$ for an organic system. (van der Zee et al., 2005). Salmonella contamination tended to be higher in conventional broiler meat $(8 \%)$ than in organic broiler meat $(4 \%)$, although the difference was not significant (Kramer et al., 2003).

\section{Product quality}

There are many aspects of a food product that determine its quality e.g., eating quality, convenience, stability, wholesomeness, nutritive value (Erdtsieck, 1989). Because

eating quality is the most direct experience of a consumer $r_{2}$ is is used often as a

measurement for product quality. Eating quality jncludes characteristics such as texture

(e.g., tenderness), appearance (e.g., colour), and flavour (taste and odour).

To be successful in an economic sense, a food product, in this case meat of a broiler, should meet the preferences and expectations of the consumer. To test this, consumers are asked to judge broiler products in blind tests. Farmer et al. (1997) used 8 trained panellists to compare breast and thigh meat from slow growing male broilers

\begin{tabular}{|c|}
\hline $\begin{array}{l}\text { Deleted: . In another Dutch study, no } \\
\text { statistical difference was found } \\
\text { between Campylobacter presence on } \\
\text { organic ( } 49 \% \text { ) and on conventional } \\
(43 \%) \text { broiler meat }\end{array}$ \\
\hline Deleted: Kramer \\
\hline Formatted: Font: Italic \\
\hline Deleted: 2003) \\
\hline Field Code Changed \\
\hline $\begin{array}{l}\text { Deleted: . A Danish research for } \\
\text { Campylobacter presence in organic } \\
\text { and conventional broiler production } \\
\text { using cloacal swabs at slaughter } \\
\text { showed that Campylobacter was } \\
\text { isolated from } 100 \% \text { of organic flocks } \\
\text { and from } 36.7 \% \text { of conventional } \\
\text { flocks }\end{array}$ \\
\hline Field Code Changed \\
\hline Deleted: Heuer \\
\hline Formatted: Font: Italic \\
\hline Deleted: 2001) \\
\hline $\begin{array}{l}\text { Deleted: indicating a high risk for } \\
\text { the meat to be contaminated when } \\
\text { birds are slaughtered, especially } \\
\text { organic poultry meat. } \\
\text { Salmonella spp. are a second group } \\
\text { of zoonotic pathogens for which } \\
\text { broiler meat is a major cause of } \\
\text { infections }\end{array}$ \\
\hline Field Code Changed \\
\hline Deleted: (Humphrey, 2006) \\
\hline $\begin{array}{l}\text { Deleted: . Conventional poultry meat } \\
\text { tends to be contaminated with } \\
\text { Salmonella more often. The } \\
\text { percentage of samples of fresh } \\
\text { chicken products taken over a whole } \\
\text { year that were contaminated with } \\
\text { Salmonella spp. was for conventional } \\
\text { broilers } 11.2 \% \text { in } 2003 \text { and } 7 . . . .\end{array}$ \\
\hline Field Code Changed \\
\hline Deleted: (van der Zee et al., 2005) \\
\hline Deleted: . Although in the stl ... [39] \\
\hline Field Code Changed \\
\hline Deleted: (2003) \\
\hline Deleted: also no statistical $\ldots[40]$ \\
\hline Deleted: of a food product \\
\hline Deleted: with a product \\
\hline Deleted: in some studies \\
\hline Deleted: an \\
\hline Deleted: Some aspects of ec ... [41] \\
\hline Deleted: is, therefore, hard to ... [42] \\
\hline Deleted: ) which in studies ar ... [43] \\
\hline Formatted: Indent: First line: $36 \mathrm{pt}$ \\
\hline Deleted: meat \\
\hline
\end{tabular}


3
493 (4.25 birds per $\mathrm{m}^{2}$, but birds were not kept according to organic regulations) at 83 days of age and fast growing male broilers ( 17 birds per $\mathrm{m}^{2}$, conventionally kept) at 48 days of age They found that the appearance of cooked breast meat from slow growers was more uniform in colour and had more visible moisture than from fast growers. They found also that the texture of breast meat from slow growers was less tough, fibrous, and resistant to the knife than that from fast growers. Results for the same indicators, however, were the opposite when judging the thigh meat. A consumer panel of 100 found that breast meat from medium-slow growers at 56 days of age was less juicy and tender, and tougher than breast meat of fast growers at 42 days of age (van Horne et al., 2003). No difference was found for thigh meat. Another consumer panel of 90 found no difference for tenderness between breast meat of slow growing broilers with outdoor access and fast growing broilers kept indoor, both slaughtered at the same weight (Fanatico et al., 2006). Juiciness of breast meat from fast growers kept indoors was judged better than from slow growers with access to outdoors.

Furthermore, breast meat from fast growers had a higher odour intensity than breast meat from slow growers (Farmer et al., 1997). Breast meat of medium_slow growers, however, had a better odour and appearance than fast growers (van Horne et al., 2003) In thigh meat the odour intensity, qualified as "chicken odour" and "abonormal odour", was higher in fast growers than in slow growers (Farmer et al., 1997). Fast, growers kept indoors scored a higher for flavour of thigh meat than slow growers with access to outdoors (Fanatico et al., 2006), but Farmer et al. (1997) did not find such a difference for flavour. as age, genotype, sex and weight of the birds; feed, housing system, way of preparing the samples, and cultural background of the panellists. These factors were not similar between different studies, which makes a comparison between, and interpretation over studies hard. Product quality, nevertheless, can be a useful indicator when used carefully, 


\section{Working conditions}

522 Working conditions concern the farmer. Relevant indicators for working conditions

523 include, for example, working hours, and number of physical and psychological

complaints related to work (Dinten et al., 2006; Mollenhorst et al., 2006). Although

$\underline{\text { there are a number of indicators regarding working conditions, there is little information }}$ $\underline{\text { regarding conventional and organic systems. }}$

$$
\text { Several studies were conducted on the levels of dust and gaseous pollutants in }
$$

broilers houses that might be detrimental for humans. Main sources of dust are from feed, litter, and the broilers themselves (Wathes, 2004). Dust can carry bacteria, viruses, and endotoxins (Takai et al., 1998). Takai et al. (1998) discriminated between $\underline{\text { respirable dust (between } 0.5-7 \mu \mathrm{m}) \text { and inhalable dust (between 7-20 } \mu \mathrm{m}) \text {. Amount of }}$ $\underline{\text { dust is dependent on time of day, time of production period, ventilation, moisture, }}$ animal activity, etc. In Dutch broiler houses, a mean concentration of $1.05 \mathrm{mg} / \mathrm{m}^{3}$ respirable dust and of $10.4 \mathrm{mg} / \mathrm{m}^{3}$ inhalable dust, and a mean concentration of 41 $\underline{\mathrm{ng} / \mathrm{m}^{3} \text { respirable endotoxins and of } 381 \mathrm{ng} / \mathrm{m}^{3} \text { inhalable endotoxins were found (Takai }}$ et al., 1998). Dust and the attached endotoxins in the pig house caused disorders in the bronchi and lungs of the farmer (Donham et al., 1984; Vogelzang, 1999; Von Essen et al., 2005). Bongers et al. (1987) concluded that respiratory problems are found more $\underline{\text { frequently in farmers than in other professional groups. }}$

Gaseous pollutants also affect working conditions. Ammonia, for example, $\underline{\text { irritates eyes and respiratory system. In the EU, the maximum acceptable }}$ concentration for ammonia is $50 \mathrm{ppm}$. For poultry houses, it is advised to keep ammonia concentration below 25 ppm, because above this level ammonia has a detrimental effect on the body weight gain of chickens (Miles et al., 2004) and severity of clinical corneal lesions increased (Miles et al., 2006). In the Netherlands, an ammonia concentration of $11.2 \mathrm{ppm}$ was found in conventional broiler houses with 
The objective of this study was to gain more insight into the contribution to sustainable

peaks up to $40 \mathrm{ppm}$ (Groot Koerkamp et al., 1998), but no such studies were found for organic broiler production .

\section{GENERAL DISCUSSION AND CONCLUSION}

development of two broiler production systems, conventional and organic, by quantifying issues related to economic, ecological ${ }_{2}$ and social, performance. Our results showed that economic performance was better for the organic system than for the conventional system, but that economic results depend on the market price for broiler meat and on feed costs. Data on economic performance, therefore, are valid for a specific time period and should be interpreted with care.

Regarding ecological performance, on-farm ammonia emission per kg live weight was higher in an organic system than in a conventional system. Because of the outdoor run ${ }_{1}$ organic production has an increased risk for eutrophication. Moreover. emission of green house gasses, use of fossil fuels and land required for the production of one $\mathrm{kg}$ of live weight is higher for an organic than for a conventional system. This is mainly due to a lower feed conversion in an organic system and use of organic, feed.

Regarding the social issue of animal welfare, many studies have been conducted that have Jead to a variety of suitable indicators. Not all indicators are ready to use. Total mortality, e.g., is a good indicator, but detailed data are needed to be able to quantify causes of death properly. From these studies, we can conclude, that slow growers in organic or extensive systems have better chances to maintain an acceptable level of welfare than fast growers in conventional systems.

Regarding the social issue of food safety, meat from an organic system was never found to be contaminated with antibiotics, in contrast to conventional system In meat of both systems, however, antibiotic resistant organisms were found. The risk for Campylobacter contamination in broiler meat was higher in an organic system than in a

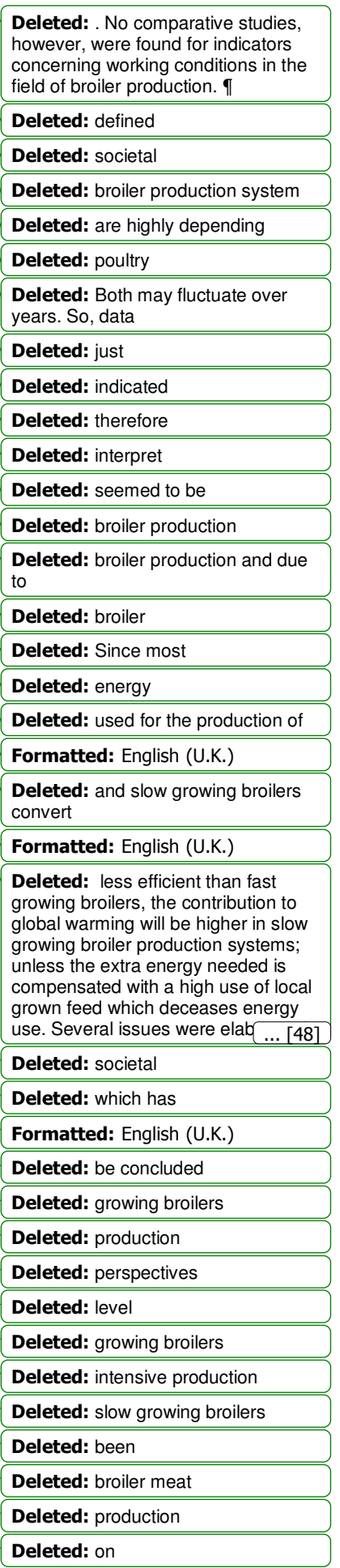


592 production system.

593 In conclusion, this study showed that changing to an organic broiler production 594 system has consequences for more than only animal welfare. Although it is difficult to 595 compare different indicators for each issue, it is necessary to study the contribution to 596 sustainable development of all jssues. An jntegrated on-farm assessment is needed to

600 We would like to thank Marieke Klaasen for her valuable help with collecting data and 601$$
\underline{M}
$$

conventional system, whereas the risk for Salmonella contamination was lower. In both systems, therefore, improvements can be made in relation to food safety.

Product quality has been found to be a difficult issue to quantify. Although

several studies on product quality were found, results were difficult to compare and to interpret due to multi-factorial effects. In future studies more attention should be paid to

these factors influencing product quality.

Finally, no data were found to quantify issues relating to working conditions.

Indirect variables were described ${ }_{2}$ and that could give an indication ${ }_{2}$ but these variables

were only available for a conventional system of broiler production.

Although assumptions had to be made for several issues, basically the methodology of Mollenhorst and De Boer (2004) was useful to assess sustainable

development in these two defined broiler production systems. It has become clear now

that the studied systems differ and what knowledge js lacking to make a good comparison for all jssues. To increase our knowledge, a next step should be an integrated ${ }_{2}$ on-farm assessment. By collecting data on farms, a quantification of all jndicators should be possible. In that way, insight can be gained into how issues affect each other and thus into the trade-offs when taking measurements to innovate a broiler fill in the gaps. In this way a production system can be developed that is economically profitable, ecologically sound, and socially acceptable.

\section{ACKNOWLEDGEMENT}

Formatted: Indent: First line: $36 \mathrm{pt}$

Deleted: for several issues

Deleted: where

Deleted: production

Deleted: kind of

Deleted: about different issues Deleted: relevant Deleted: Deleted: relevant Deleted: in Deleted: change something in

Deleted: over

Deleted: a slow growing

Deleted: much more Deleted: for

Deleted: relevant

Deleted: After this approach based upon current knowledge, an

Deleted:

Deleted: acceptable for society,

Deleted: and

a

Formatted: Default Paragraph Font, English (U.S.)

Formatted: Body Text 2

Formatted: Default Paragraph Font, English (U.S.) 
603

604

605

606

607

608

609

610

611

612

613

614

615

616

617

618

619

620

621

622

623

624

625

626

627

AARNINK, A.J.A., HOL, J.M.G. \& BEURSKENS, A.G.C. (2006) Ammonia emission and nutrient load in outdoor runs of laying hens. Wageningen Journal of Life Sciences, 54: 223-234.

ALTEKRUSE, S.F., HUNT, J.M., TOLLEFSON, L.K. \& MADDEN, J.M. (1994) Food and animal sources of human Campylobacter jejuni infection. Journal of the American Veterinary Medical Association, 204: 57-61.

BELL, S. \& MORSE, S. (1999) Sustainability indicators: measuring the immeasurable? (London, UK, Earthscan Publications Ltd).

BESSEI, W. (2006) Welfare of broilers: a review. World's Poultry Science Journal, 62: 455-466.

BLONK, H., ALVARADO, C. \& DE SCHRIJVER, A. (2007) Milieuanalyse vleesproducten. PRé Consultants, Amersfoort; Blonk Milieu Advies, Gouda, pp. 36.

BOKKERS, E.A.M. \& KOENE, P. (2003) Behaviour of fast- and slow growing broilers to 12 weeks of age and the physical consequences. Applied Animal Behaviour

Deleted: ARENS, P.J., 2000. Onderzoek naar het gedrag, loopvermogen en voeropname bij vleeskuikens en legkuikens. pp. 27 Wageningen: Dierwetenschappen,

Wageningen University. $\uparrow$

\begin{tabular}{l}
\hline Deleted: ., \\
\hline Deleted: . \\
\hline Formatted: Font: Italic, English \\
(U.K.) \\
\hline Formatted: English (U.K.) \\
\hline Deleted: pp. 36: \\
\hline Formatted: English (U.K.) \\
\hline Formatted: English (U.K.)
\end{tabular}
Science, 81: 59-72.

BOKKERS, E.A.M., ARENS, P.J. \& KOENE, P. (2000) Behavioural abilities of broilers and layer chicks on two diets. Xth International Congress on Animal Hygiene, Maastricht, the Netherlands, pp. 468-470.

BOKKERS, E.A.M., ZIMMERMAN, P.H., RODENBURG, T.B. \& KOENE, P. (2007)

Deleted: BAS Walking behaviour of heavy and light broilers in an operant runway test with varying durations of feed deprivation and feed access. Applied Animal Behaviour Science, 108: 129-142.

BOLHUIS, J. \& WISMAN, A. (2007) Eerste kwartaal vleeskuikens: resultaten verbeterd, maar nog weinig inkomen. _LEI, Wageningen UR, pp. 2.

Deleted: .

Deleted: .

Formatted: Font: Italic

Deleted: In: Agrimonitor, pp. 2:

Formatted: Dutch (Netherlands) 
1

BONGERS, P., HOUTHUIJS, D., REMIJN, B., BROUWER, R. \& BIERSTEKER, K. (1987) Lung function and respiratory symptoms in pig farmers. British Journal of Industrial Medicine, 44: 819-823.

CORR, S.A., GENTLE, M.J., MCCORQUODALE, C.C. \& BENNETT, D. (2003a) The effect of morphology on the musculoskeletal system of the modern broiler. Animal Welfare, 12: 145-157.

CORR, S.A., GENTLE, M.J., MCCORQUODALE, C.C. \& BENNETT, D. (2003b) The effect of morphology on walking ability in the modern broiler: a gait analysis study. Animal Welfare, 12: 159-171.

DE BOER, I.J.M. (2003) Environmental impact assessment of conventional and organic milk production. Livestock Production Science, 80: 69-77.

DE BOER, I.J.M. \& CORNELISSEN, A.M.G. (2002) A method using sustainability indicators to compare conventional and animal-friendly egg production systems. Poultry Science, 81: 173-181.

DINTEN, C.A.M., ABRAHAO, R.F. \& DE OLIVEIRA, J.T.A. (2006) Work organization and technological resources in broiler production - an ergonomics approach. Scientia Agricola, 63: 46-54.

DONHAM, K.J., ZAVALA, D.C. \& MERCHANT, J.A. (1984) Respiratory symptoms and lung function among workers in swine confinement buildings: a cross-sectional epidemiological study. Archives of Environmental Health, 39: 96-101.

DYER, J.A. \& DESJARDINS, R.L. (2006) An Integrated Index of Electrical Energy Use in Canadian Agriculture with Implications for Greenhouse Gas Emissions. Biosystems Engineering, 95: 449-460.

EKSTRAND, C., CARPENTER, T.E., ANDERSSON, I. \& ALGERS, B. (1998) Prevalence and control of foot-pad dermatitis in broilers in Sweden. British Poultry Science, 39: 318-324.

ELLENDORFF, F. (2002) Comparison of broiler production systems. Archiv für Geflügelkunde, 66: 58. 
ERDTSIECK, B. (1989) Quality requirements in the modern poultry industry in: MEAD, G.C. (Eds.), Processing of Poultry, pp. 1-30 (New York, Elsevier Applied Science).

EU (1991) Council Directive 91/676/EEC of 12 December 1991 concerning the protection of waters against pollution caused by nitrates from agricultural sources.

EU (1999) Council Regulation (EC) No 1804/1999 of 19 July 1999 supplementing Regulation (EEC) No 2092/91 on organic production of agricultural products and indications referring thereto on agricultural products and foodstuffs to include livestock production. Official Journal, L 222: 0001-0028.

$\mathrm{EU}(2000)_{\alpha}$ The welfare of chickens kept for meat production (broilers). ${ }_{-}$Report of the Scientific Committee on Animal Health and Animal Welfare, European Commission, Health \& Consumer Protection Directorate-General, pp. 149. FANATICO, A.C., PILLAI, P.B., CAVITT, L.C., EMMERT, J.L., MEULLENET, J.F. \& OWENS, C.M. (2006) Evaluation of slower-growing broiler genotypes grown with and without outdoor access: sensory attributes. Poultry Science, 85: 337343.

FARMER, L.J., PERRY, G.C., LEWIS, P.D., NUTE, G.R., PIGGOTT, J.R. \& PATTERSON, R.L.S. (1997) Responses of two genotypes of chicken to the diets and stocking densities of conventional UK and Label Rouge production systems II. Sensory attributes. Meat Science, 47: 77-93.

FAWC (1992) FAWC updates the five freedoms. The Veterinary Record, 131: 357.

GONZALES, E., BUYSE, J., SARTORI, J.R., LODDI, M.M. \& DECUYPERE, E. (1999) Metabolic disturbances in male broilers of different strains. 2. Relationship between the thyroid and somatotropic axes with growth rate and mortality. Poultry Science, 78: 516-521.

GORDON, S.H. (1992) The effect of broiler stocking density on bird welfare and performance. British Poultry Science, 33: 1120-1121.

Deleted:
Deleted: .
Deleted: pp. 149:
Formatted: Font: Italic

Deleted: ). Deleted:

Formatted: English (U.K.) 
684 GORDON, S.H. \& CHARLES, D.R. (2002) Niche and Organic Chicken and Egg

685 Products: Their technology and scientific principles. (Nottingham, United

GROENESTEIN, C.M., VAN DER HOEK, K.W., MONTENY, G.J. \& OENEMA, O. (2005).Actualisering forfaitaire waarden voor gasvormige $N$-verliezen uit stallen en mestopslagen. 465 Agrotechnology \& Food Innovations, pp. 36 systems for laying hens in relation to sources, processes, building design and manure handling. Journal of Agricultural Engineering Research, 59: 73-87.

GROOT KOERKAMP, P.W.G., METZ, J.H.M., UENK, G.H., PHILLIPS, V.R., HOLDEN, M.R., SNEATH, R.W., SHORT, J.L., WHITE, R.P.P., HARTUNG, J. \& SEEDORF, J. (1998) Concentrations and emissions of ammonia in livestock buildings in Northern Europe. Journal of Agricultural Engineering Research, 70: 79-95.

HALL, A.L. (2001) The effect of stocking density on the welfare and behaviour of broiler chickens reared commercially. Animal Welfare, 10: 23-40.

HAVENSTEIN, G.B., FERKET, P.R. \& QURESHI, M.A. (2003) Carcass composition and yield of 1957 versus 2001 broilers fed representative 1957 and 2001 broiler diets. Poultry Science, 82: 1509-1518.

HERMANSEN, J.E., STRUDSHOLM, K. \& HORSTED, K. (2004) Integration of organic animal production into land use with special reference to swine and poultry. Livestock Production Science, 90: 11-26.

HEUER, O.E., PEDERSEN, K., ANDERSEN, J.S. \& MADSEN, M. (2001) Prevalence and antimicrobial susceptibility of thermophilic Campylobacter in organic and conventional broiler flocks. Letters in Applied Microbiology, 33: 269-274. HUMPHREY, T. (2006) Are happy chickens safer chickens? Poultry welfare and disease susceptibility. British Poultry Science, 47: 379-391. 


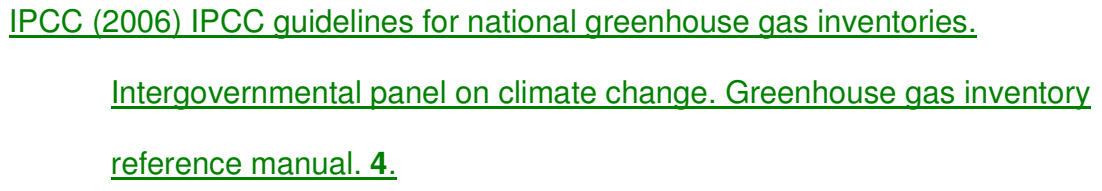

KESTIN, S.C., GORDON, S.H., SU, G. \& SøRENSEN, P. (2001) Relationships in broiler chickens between lameness, liveweight, growth rate and age. The Veterinary Record, 148: 195-197.

KRAMER, G., LUIJK, R. \& GROOTHUIS, K. (2003)Integrale vergelijking van regulier en biologisch kippenvlees, maatschappelijke aspecten en voedselveiligheid. . Afdeling Onderzoek van de Consumentenbond, pp. 73.

KWIN (2003-2004) Kwantitatieve Informatie Veehouderij. _(Wageningen, the

Deleted: ., Deleted: .

Formatted: Font: Italic Deleted: pp. 73. the Netherlands: KWIN (2006) Kwantitatieve Informatie Veehouderij. (Wageningen, the Netherlands, Animal Sciences Group, Wageningen UR).

LILBURN, M. (1994) Skeletal growth of commercial poultry species. Poultry Science, 73: 897-903.

MILES, D.M., BRANTON, S.L. \& LOTT, B.D. (2004) Atmospheric ammonia is detrimental to the performance of modern commercial broilers. Poultry Science, 83: $1650-1654$.

MILES, D.M., MILLER, W.W., BRANTON, S.L., MASLIN, W.R. \& LOTT, B.D. (2006) Ocular responses to ammonia in broiler chickens. Avian Diseases, 50: 45-49. MITCHELL, G., MAY, A. \& MCDONALD, A. (1995) PICABUE: a methodological framework for the development of indicators of sustainable development. International Journal of Sustainable Development and World Ecology, 2: 104123. 
MOLLENHORST, H. \& DE BOER, I.J.M. (2004) Identifying sustainability issues using participatory SWOT analysis. Outlook on Agriculture, 33: 267-276.

MOLLENHORST, H., BERENTSEN, P.B.M. \& DE BOER, I.J.M. (2006) On-farm quantification of sustainability indicators: an application to egg production systems. British Poultry Science, 47: 405-417.

NESTOR, K.E., BACON, W.L., SAIF, Y.M. \& RENNER, P.A. (1985) The influence of genetic increases in shank width on body weight, walking ability, and reproduction of turkeys. Poultry Science, 64: 2248-2255.

OENEMA, O., VELTHOF, G.L., VERDOES, N., GROOT KOERKAMP, P.W.G., MONTENY, G.J., BANNINK, A., VAN DER MEER, H.G. \& VAN DER HOEK,

PAGAZAURTUNDUA, A. \& WARRISS, P.D. (2006) Levels of foot pad dermatitis in K.W. (2000) Forfaitaire waarden voor gasvormige stikstofverliezen uit stallen en mestopslagen. Alterra-rapport 107 Wageningen UR, RIVM, pp. 185. 
SCHEELE, C.W., (1996) Ascites in broilers, oxygen consumption and requirement

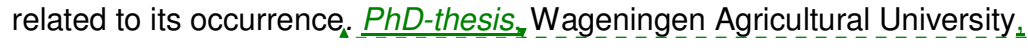
Wageningen, the Netherlands.

SKAL_(2004)SKal-Tarievenblad 2004. R16, Stichting Skal, certificatie biologische productie, pp. 10.

SPEDDING, C.R.W., THOMPSON, A.M.M. \& JONES, M.R. (1983) Energy and economics of intensive animal production. Agro-Ecosystems, 8: 169.

SU, G., SØRENSEN, P. \& KESTIN, S.C. (2000) A note on the effects of perches and litter substrate on leg weakness in broiler chickens. Poultry Science, 79: 12591263.

TACKEN, G., DE WINTER, M. \& WERTHEIM-HECK, S. (2007) De invloed van meerwaarde van biologische producten op consumentenaankopen; Consumentenperceptie van biologische producten in de supermarkt. Rapport 5.07.02, Landbouw Economisch Instituut, pp. 91.

TACKEN, G.M.L., GODDIJN, S.T. \& VAN HORNE, P.L.M. (2003),Biologisch pluimveevlees in Frankrijk. Rapport 2.03.19, Landbouw Economisch Instituut, pp. 96.

TAKAI, H., PEDERSEN, S., JOHNSEN, J.O., METZ, J.H.M., GROOT KOERKAMP,

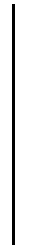
P.W.G., UENK, G.H., PHILLIPS, V.R., HOLDEN, M.R., SNEATH, R.W.\& SHORT, J.L (1998) Concentrations and Emissions of Airborne Dust in Livestock Buildings in Northern Europe. Journal of Agricultural Engineering Research, 70: 59.

TASISTRO, A.S., KISSEL, D.E. \& BUSH, P.B. (2004) Spatial variability of broiler litter composition in a chicken house. Journal of Applied Poultry Research, 13: 29$\underline{43 .}$

THOMASSEN, M.A., (2008) Environmental impact of dairy cattle production systems: an integral assessment. PhD thesis, Wageningen University, Wageningen, the Netherlands,

Formatted: Dutch (Netherlands) Deleted: .,

Formatted: Dutch (Netherlands) Deleted: .

Formatted: Dutch (Netherlands)

Formatted: Font: Italic

Deleted: pp. 91. Den Haag, the Netherlands:

Deleted: .,

Deleted: .

Formatted: Font: Italic

Deleted: pp. 96. Den Haag:

Deleted:

Deleted: WHITE R.P HARTUNG J., SEEDORF, J., SCHRODER, M., LINKERT, K.H. \& WATHES, C.M

Deleted: emissions of airborne dust in livestock buildings 
THOMASSEN, M.A. \& DE BOER, I.J.M. (2005) Evaluation of indicators to assess the environmental impact of dairy production systems. Agriculture, Ecosystems \& Environment, 111: 185-199.

TURNER, J., GARCÉS, L. \& SMITH, W. (2003) The welfare of broiler chickens in the European Union. Compassion in World Farming Trust, pp. 32.

VAN CALKER, K.J., BERENTSEN, P.B.M., GIESEN, G.W.J. \& HUIRNE, R.B.M. (2005) Identifying and ranking attributes that determine sustainability in Dutch dairy farming. Agriculture and Human Values, 22: 53-63.

VAN CALKER, K.J., BERENTSEN, P.B.M., DE BOER, I.M.J., GIESEN, G.W.J. \& HUIRNE, R.B.M. (2004) An LP-model to analyse economic and ecological sustainability on Dutch dairy farms: model presentation and application for experimental farm "de Marke". Agricultural Systems, 82: 139-160.

VAN DEN TEMPEL, F.C.A. \& GIESEN, G.W.J. (1992) Agrarische bedrijfseconomie: inleiding. (Culemborg, the Netherlands, Educaboek).

VAN DER ZEE, H., WIT, B. \& VOLLEMA, A.R. (2005),Survey pathogenen en bateriële resistentie in kipproducten uit biologische teelt, Jaar 2004. Voedsel en Waren Autoriteit / Keuringsdienst van Waren Oost, pp. 10.

Deleted: . Deleted: .

Formatted: Font: Italic Deleted: pp. 10. Zutphen, the Netherlands:

VAN HORNE, P.L.M., VAN HARN, J.V., VAN MIDDELKOOP, J.H. \& TACKEN, G.M.L. (2003) Perspectieven voor een alternatieve kuikenvleesketen. Rapport 2.03.20, Landbouw Economisch Instituut, pp. 66.

VERMEIJ, I. (2004) Primaire productiekosten biologische kuikenvlees. Intern rapport 505. Animal Sciences Group, Wageningen UR, pp. 19.

VOGELZANG, P., (1999) Airway disease and risk factors in pig farmers. PhD thesis, Catholic University Nijmegen, Nijmegen, the Netherlands.

VON ESSEN, S.G., ANDERSEN, C.I. \& SMITH, L.M. (2005) Organic dust toxic syndrome: a noninfectious febrile illness after exposure to the hog barn environment. Journal of Swine Helath and Production, 13. 
820

WATHES, C.M. (2004) Air hygiene ${ }_{-}$in: WEEKS, C.A. \& BUTTERWORTH, A. (Eds.), Measuring and Auditing Broiler Welfare, pp. 117-131 (Wallingford, UK, CABI Publishing).

WEEKS, C.A. (2002) Some behavioural differences between fast and slow-growing strains of poultry. British Poultry Science, 43: S24-S26.

WEEKS, C.A., NICOL, C.J., SHERWIN, C.M. \& KESTIN, S.C. (1994) Comparison of the behaviour of broiler chickens in indoor and free-range environments. Animal Welfare, 3: 179-192.

WILLIAMS, A.G., AUDSLEY, E. \& SANDARS, D.L. (2006) Determining the environmental burdens and resource use in the production of agricultural and horticultural commodities. Main report. Defra Research Project ISO205. $\underline{\text { available on www.silsoe.cranfield.ac.uk and www.defra.gov.uk. Cranfield }}$ $\underline{\text { University and Defra, pp. } 97 .}$ 

2003.

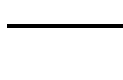

$-$

Technical data

Duration of a round (days)

Empty for cleaning (days)

Rounds per year (number)

Space inside (birds per $m^{2}$ )

Space outdoor ( $\mathrm{m}^{2}$ per bird)

Mortality (\%)

Birds slaughtered per round (number)

Slaughter weight $(\mathrm{g})$

Total delivered (kg_per year)

Growth (g per day)

Feed conversion ( $\mathrm{kg}$ feed per $\mathrm{kg}$ growth)

Feed intake per round (g per, bird)

Water intake per round (I per,bird)

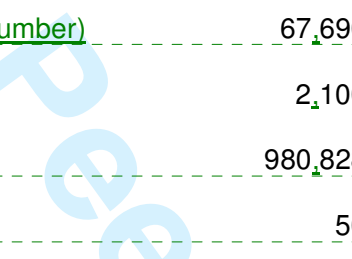

70,000

Broiler production system

Organic

\begin{tabular}{cc} 
Organic \\
\hline 43 & 16,000 \\
10 & 70 \\
\end{tabular}

\section{6}

$22 \ldots \ldots$

0

3.3

Deleted: (KWIN, 2003-2004, 2006)
Deleted: (Vermeij, 2004)
Deleted: the year

Formatted Table

Deleted: Broilers

Deleted: Number of birds

Deleted: /

Formatted: Not Superscript/ Subscript

Deleted:

Deleted: Number of birds

\section{Deleted: /}

Deleted: /

Deleted:

Deleted: /

Deleted: / round

Deleted:

Deleted: / round

Deleted:

Deleted: -----------.Page Break--------.--

Table 2: Economic data of a

Formatted: Font: $10 \mathrm{pt}$

Deleted: and an

Formatted: Font: $10 \mathrm{pt}$

Deleted: broiler production system

Formatted: Font: $10 \mathrm{pt}$ 
Table 2: Economic data of a conventional and an organic broiler production system for

839 the year 2003.

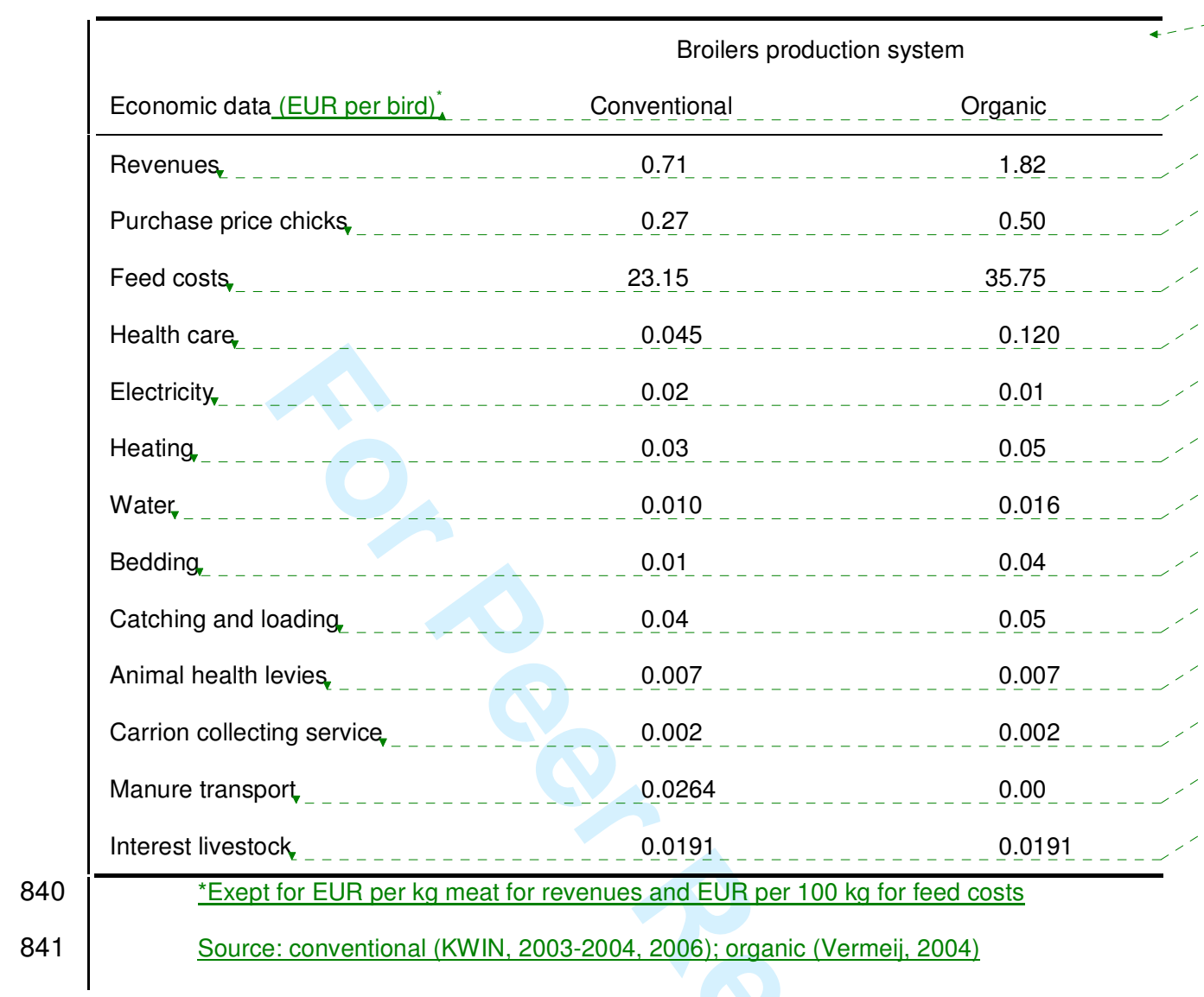

Formatted Table

Formatted: Superscript

Deleted: (€/kg meat)

Deleted: (€/bird)

Deleted: $(€ / 100 \mathrm{~kg})$

Deleted: (€/bird)

Deleted: (€/bird)

Deleted: (€/bird)

Deleted: ( $€ /$ bird)

Deleted: (€/bird)

Deleted: (€/bird)

Deleted: $(€ /$ bird $)$

Deleted: $(€ /$ bird $)$

Deleted: $(€ /$ bird $)$

Deleted: $(€ /$ bird $)$ 


\section{2

Table 3: Annual economic performance of a conventional and an organic broiler

production system for 2003 in EUR per FTE.

Broiler production system

Total revenues

Variable costs

Feed

One-day-old chicks

Health care

Electricity

Heating

Water

Bedding

Catching and loading

Animal health levies

Carcass collecting service

Interest livestock

Total variable costs

Fixed costs

Depreciation and maintenance of buildings

Depreciation and maintenance of inventory

Outdoor run

Manure transport

Control levies organic

Other fixed costs

Total fixed costs

Net farm income

\begin{tabular}{|c|c|}
\hline $399,629.38$ & $165,260.94$ \\
\hline $130_{1} 410.00$ & $36,800.00$ \\
\hline $21_{1} 735.00$ & $8,832.00$ \\
\hline $9,660.00$ & 736.00 \\
\hline $14,490.00$ & $3,680.00$ \\
\hline $4,830.00$ & $1,209.14$ \\
\hline $4,830.00$ & $2,944.00$ \\
\hline $19,320.00$ & $3,680.00$ \\
\hline $3,381.00$ & 515.20 \\
\hline 966.00 & 147.20 \\
\hline $9,225.30$ & 1.405 .76 \\
\hline $618_{1} 476.68$ & $225_{1} 210.24$ \\
\hline $25_{2} 772.73$ & $10,240.00$ \\
\hline $18,931.82$ & $4,080.00$ \\
\hline 0.00 & $8,640.00$ \\
\hline $12,751.20$ & 0.00 \\
\hline 0.00 & $3,940.00$ \\
\hline $13_{2}, 000.00$ & $13,000.00$ \\
\hline $70_{2} 455.75$ & $39_{2} 900.00$ \\
\hline $7,455.52$ & $73,413.26$ \\
\hline
\end{tabular}

844
Deleted: Economic

Deleted: the year 2003 
Page 2: [1] Formatted

bokke001

12/23/2008 12:35:00 PM

Left, Numbered + Level: $1+$ Numbering Style: 1, 2, 3, $\ldots+$ Start at: $1+$ Alignment: Left + Aligned at: 0 $\mathrm{pt}+$ Tab after: $28.35 \mathrm{pt}+$ Indent at: $0 \mathrm{pt}$, Tabs: $14.2 \mathrm{pt}$, List tab + Not at $28.35 \mathrm{pt}$

\begin{tabular}{ccc}
\hline Page 2: [2] Deleted & bokke001 & 12/23/2008 12:35:00 PM \\
has much more consequences than & &
\end{tabular}

Page 2: [3] Deleted bokke01 12/23/2008 12:35:00 PM

. Although it is difficult to compare different indicators for each issue, it is necessary to

\begin{tabular}{lcc}
\hline Page 2: [4] Deleted & bokke001 & $\mathbf{1 2 / 2 3 / 2 0 0 8 ~ 1 2 : 3 5 : 0 0 ~ P M ~}$ \\
the contribution to sustainable development of all relevant issues. An
\end{tabular}

Page 2: [5] Deleted

bokke001

12/23/2008 12:35:00 PM

for that. In this way a production system

$\begin{array}{cc}\text { Page 2: [6] Formatted } & \text { bokke001 } \\ \text { English (U.S.), Do not check spelling or grammar } & 12 / 23 / 2008 \text { 12:35:00 PM }\end{array}$

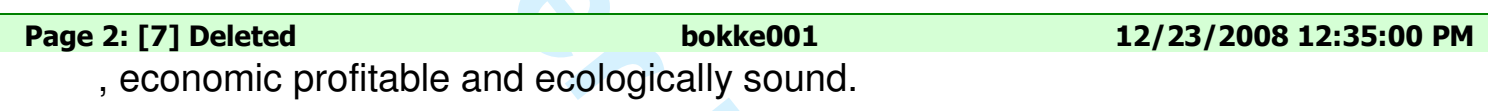

Page 4: [8] Deleted bokke001 12/23/2008 12:35:00 PM

in egg production systems. Organic regulations, for example, determine that animals

should have outdoor access for a certain period of their life or of the year. This might

have, next to improved animal welfare, negative environmental consequences such as a

higher ammonia volatilisation or nitrogen leaching

\begin{abstract}
Page 4: [9] Deleted bokke001 12/23/2008 12:35:00 PM
. Making a well reasoned holistic consideration whether one production system

contributes more to sustainable development than another, therefore, requires a

comparison of the economic, ecological and societal performance of both production

systems. In other words, the contribution of a system with slow growing broilers and a

system with fast growing broilers to sustainable development should be assessed. In this study, we compared the combined economic, ecological and societal performance of a defined organic production system with slow growing broilers with a defined conventional production system with fast growing broilers.
\end{abstract}




\title{
MATERIALS AND METHODS
}

The four step methodology used in this study is based on ideas of Bell and Morse

\begin{abstract}
Page 5: [10] Deleted
bokke001

12/23/2008 12:36:00 PM

and seems to be useful to apply for other production systems as well. It consists of the

following steps: 1) description of the problem situation and of the system in study, 2)

identification and definition of relevant economic, ecological en societal issues, 3)

selection and quantification of indicators for each issue, and 4) final assessment of the

contribution to sustainable development. These four steps are described in more detail.
\end{abstract}

Step (1): Description of the problem situation and the system in study

The first step requires a description of the problem situation and of the systems in study.

The problem situation is described in the introduction. The systems in study are a defined conventional broiler production system with fast growing broilers and a defined organic broiler production system with slow growing broilers managed by one full time equivalent. The system boundary is therefore the farm with inputs such as feed, water, electricity, medicines, litter, one-day old chicks, etc., and with broilers for slaughter and manure as output.

Step (2): Identification and definition of economic, ecological and societal issues The second step implies the selection of economic, ecological and societal (EES) issues relevant regarding sustainable development of a broiler production farm. Based on recent assessment studies (Mollenhorst and de Boer, 2004; van Calker et al., 2004), we selected the following EES issues: economic performance

\begin{tabular}{ccc}
$\begin{array}{c}\text { Page 13: [11] Deleted } \\
\text { much }\end{array}$ & bokke001 & 12/23/2008 12:36:00 PM \\
\hline $\begin{array}{c}\text { Page 13: [11] Deleted } \\
\text { In addition }\end{array}$ & bokke001 & $12 / 23 / 2008$ 12:36:00 PM \\
\hline
\end{tabular}




\begin{tabular}{lll}
\hline $\begin{array}{c}\text { Page 13: }[11] \text { Deleted } \\
\text { very }\end{array}$ & bokke001 & 12/23/2008 12:36:00 PM
\end{tabular}

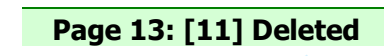

12/23/2008 12:36:00 PM

bokke001

12/23/2008 12:36:00 PM

\begin{tabular}{|c|c|c|}
\hline Page 13: [11] Deleted & bokke001 & $12 / 23 / 2008$ 12:36:00 PM \\
\hline \multicolumn{3}{|c|}{ As far as we know no } \\
\hline Page 13: [12] Deleted & bokke001 & $12 / 23 / 2008$ 12:36:00 PM \\
\hline \multicolumn{3}{|l|}{ global warming } \\
\hline Page 13: [12] Deleted & bokke001 & $12 / 23 / 2008$ 12:36:00 PM \\
\hline \multicolumn{3}{|c|}{ energy use, we distinguish } \\
\hline Page 13: [12] Deleted & bokke001 & $12 / 23 / 2008$ 12:36:00 PM \\
\hline \multicolumn{3}{|l|}{ fossil energy } \\
\hline Page 13: [12] Deleted & bokke001 & $12 / 23 / 2008$ 12:36:00 PM \\
\hline \multicolumn{3}{|l|}{ fossil energy } \\
\hline Page 13: [12] Deleted & bokke001 & $12 / 23 / 2008$ 12:36:00 PM \\
\hline \multicolumn{3}{|l|}{ comprises } \\
\hline Page 13: [12] Deleted & bokke001 & $12 / 23 / 2008$ 12:36:00 PM \\
\hline \multicolumn{3}{|l|}{ energy } \\
\hline Page 13: [12] Deleted & bokke001 & $12 / 23 / 2008$ 12:36:00 PM \\
\hline \multicolumn{3}{|l|}{ comprises } \\
\hline Page 13: [12] Deleted & bokke001 & $12 / 23 / 200812: 36: 00 \mathrm{PM}$ \\
\hline \multicolumn{3}{|l|}{ the } \\
\hline Page 13: [12] Deleted & bokke001 & $12 / 23 / 2008$ 12:36:00 PM \\
\hline
\end{tabular}

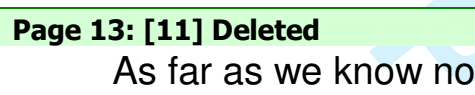

bokke001.


like

\begin{tabular}{lll}
\hline Page 13: [12] Deleted & bokke001 & $12 / 23 / 2008$ 12:36:00 PM \\
production & &
\end{tabular}

Page 13: [12] Deleted energy use comprises

bokke001

12/23/2008 12:36:00 PM energy

Page 13: [12] Deleted

bokke001

12/23/2008 12:36:00 PM

of the total energy comprises

\begin{tabular}{lc}
\hline Page 13: [12] Deleted & bokke001 \\
fossil energy required for the production &
\end{tabular}

Page 13: [13] Deleted

bokke001

12/23/2008 12:36:00 PM production

\begin{tabular}{|c|c|c|}
\hline Page 13: [13] Deleted & bokke001 & $12 / 23 / 2008$ 12:36:00 PM \\
\hline energy comprises & & \\
\hline Page 13: [13] Deleted & bokke001 & $12 / 23 / 2008$ 12:36:00 PM \\
\hline of & & \\
\hline Page 13: [13] Deleted & bokke001 & $12 / 23 / 200812: 36: 00 \mathrm{PM}$ \\
\hline and is & & \\
\hline Page 13: [13] Deleted & bokke001 & $12 / 23 / 2008$ 12:36:00 PM \\
\hline Page 13: [13] Deleted & bokke001 & $12 / 23 / 2008$ 12:36:00 PM \\
\hline
\end{tabular}

Page 13: [13] Deleted

bokke001

12/23/2008 12:36:00 PM production

\begin{tabular}{|c|c|c|}
\hline Page 13: [13] Deleted & bokke001 & $12 / 23 / 2008$ 12:36:00 PM \\
\hline
\end{tabular}
only

E-mail: br.poultsci@bbsrc.ac.uk URL: http://mc.manuscriptcentral.com/cbps 


\begin{tabular}{|c|c|c|}
\hline Page 13: [13] Deleted & bokke001 & $12 / 23 / 2008$ 12:36:00 PM \\
\hline and, therefore, & & \\
\hline Page 13: [13] Deleted & bokke001 & $12 / 23 / 2008$ 12:36:00 PM \\
\hline
\end{tabular}

Page 13: [13] Deleted $\quad$ bokke001 $\quad 12 / 23 / 2008$ 12:36:00 PM
to

\begin{tabular}{|c|c|c|}
\hline Page 13: [13] Deleted & bokke001 & $12 / 23 / 2008$ 12:36:00 PM \\
\hline production & & \\
\hline
\end{tabular}

\begin{tabular}{ll}
\hline Page 13: $[13]$ Deleted & bokke001 \\
Besides &
\end{tabular}

\begin{tabular}{|c|c|c|}
\hline Page 13: [13] Deleted & bokke001 & $12 / 23 / 2008$ 12:36:00 PM \\
\hline \multicolumn{3}{|l|}{ farms use } \\
\hline Page 13: [13] Deleted & bokke001 & $12 / 23 / 2008$ 12:36:00 PM \\
\hline Due & & \\
\hline
\end{tabular}

Page 13: [13] Deleted $\quad$ bokke001 12/23/2008 12:36:00 PM

, energy required for heating in organic broiler production is expected to double

\begin{tabular}{|c|c|c|}
\hline Page 13: [13] Deleted & bokke001 & $12 / 23 / 2008$ 12:36:00 PM \\
\hline
\end{tabular}

\begin{tabular}{lcc}
\hline Page 13: [13] Deleted & bokke001 & 12/23/2008 12:36:00 PM \\
organic production & \\
& \\
\hline Page 13: [13] Deleted & bokke001 & $12 / 23 / 2008$ 12:36:00 PM \\
to &
\end{tabular}

\begin{tabular}{|c|c|c|}
\hline Page 13: [13] Deleted & bokke001 & $12 / 23 / 2008$ 12:36:00 PM \\
\hline
\end{tabular}

\begin{tabular}{lll}
$\begin{array}{l}\text { Page 13: [14] Deleted } \\
\text { As mentioned above, }\end{array}$ & bokke001 & \\
\hline $\begin{array}{c}\text { Page 13: [14] Deleted } \\
\text { energy }\end{array}$ & bokke001 & $12 / 23 / 2008$ 12:36:00 PM \\
\hline
\end{tabular}

E-mail: br.poultsci@bbsrc.ac.uk URL: http://mc.manuscriptcentral.com/cbps 
production

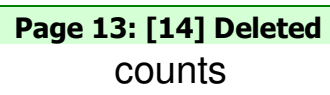

\begin{tabular}{|c|c|c|}
\hline \multirow{2}{*}{\multicolumn{3}{|c|}{$\begin{array}{l}\text { Page 16: [15] Deleted } \\
\text {. In both genotypes percentage }\end{array}$}} \\
\hline & & \\
\hline Page 16: [16] Deleted & bokke001 & $12 / 23 / 2008$ 12:36:00 PM \\
\hline
\end{tabular}

Page 16: [17] Deleted bokke001 $12 / 23 / 2008$ 12:36:00 PM Compared to chicks of a laying genotype time

Page 16: [18] Deleted bokke001 12/23/2008 12:36:00 PM of their time on walking while fast growing broilers spent $2.7 \%$ of their time on walking

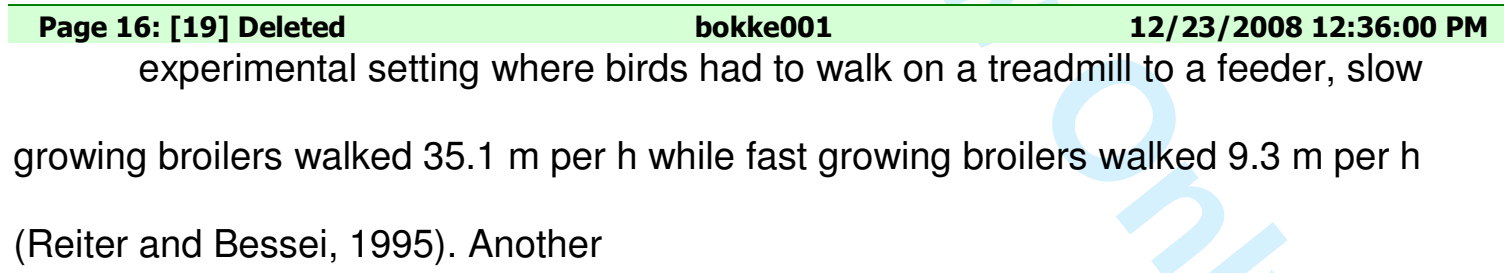
capacities of broilers is by using the gait score. The gait

Page 16: [21] Deleted bokke001

The higher the score the more welfare is

12/23/2008 12:36:00 PM

Page 16: [22] Deleted

bokke001

12/23/2008 12:36:00 PM Kestin et al. (2001) found that when fed ad libitum fast 
while

\begin{tabular}{|c|c|c|}
\hline Page 17: [28] Deleted & bokke001 & $12 / 23 / 2008$ 12:36:00 PM \\
\hline $\begin{array}{c}\text { Page 17: [28] Deleted } \\
\text { genotypes }\end{array}$ & bokke001 & $12 / 23 / 2008$ 12:36:00 PM \\
\hline $\begin{array}{l}\text { Page 17: [28] Deleted } \\
\text { foot pad dermatitis }\end{array}$ & bokke001 & $12 / 23 / 200812: 36: 00$ PM \\
\hline $\begin{array}{l}\text { Page 17: [28] Deleted } \\
\text { of age }\end{array}$ & bokke001 & $12 / 23 / 2008$ 12:36:00 PM \\
\hline $\begin{array}{l}\text { Page 17: [29] Deleted } \\
\text { foot }\end{array}$ & bokke001 & $12 / 23 / 2008$ 12:36:00 PM \\
\hline Page 17: [29] Deleted & bokke001 & $12 / 23 / 2008$ 12:36:00 PM \\
\hline Page 17: [29] Deleted & bokke001 & $12 / 23 / 2008$ 12:36:00 PM \\
\hline
\end{tabular}

8
9
10
11
12
13
14
15
16
17
18
19
20
21
22
23
24
25
26
27
28
29
30
31
32
33
34

Page 17: [29] Deleted

bokke001

$12 / 23 / 2008$ 12:36:00 PM growing broilers

\begin{tabular}{lll}
\hline $\begin{array}{c}\text { Page 17: [29] Deleted } \\
\text { inside }\end{array}$ & bokke001 & $12 / 23 / 2008$ 12:36:00 PM \\
\hline $\begin{array}{c}\text { Page 17: [29] Deleted } \\
\text { Page 17: [30] Deleted } \\
\text { Commercially grown }\end{array}$ & bokke001 & \\
\hline $\begin{array}{c}\text { Page 17: [30] Deleted } \\
\text { broilers had }\end{array}$ & bokke001 & $12 / 23 / 2008$ 12:36:00 PM \\
\hline $\begin{array}{c}\text { Page 17: [30] Deleted } \\
\text { appears }\end{array}$ & bokke001 & $12 / 23 / 2008$ 12:36:00 PM \\
\hline
\end{tabular}




\begin{tabular}{|c|c|c|}
\hline Page 17: [30] Deleted & bokke001 & $12 / 23 / 2008$ 12:36:00 PM \\
\hline \multicolumn{3}{|l|}{ food } \\
\hline Page 17: [30] Deleted & bokke001 & 12/23/2008 12:36:00 PM \\
\hline \multicolumn{3}{|c|}{ seemed to appear } \\
\hline Page 17: [30] Deleted & bokke001 & 12/23/2008 12:36:00 PM \\
\hline \multicolumn{3}{|l|}{ provided to } \\
\hline Page 17: [30] Deleted & bokke001 & 12/23/2008 12:36:00 PM \\
\hline \multicolumn{3}{|l|}{ broilers } \\
\hline Page 17: [30] Deleted & bokke001 & 12/23/2008 12:36:00 PM \\
\hline \multicolumn{3}{|c|}{ in relation to foot pad lesions } \\
\hline Page 17: [31] Deleted & bokke001 & $12 / 23 / 2008$ 12:36:00 PM \\
\hline \multicolumn{3}{|l|}{ problems } \\
\hline Page 17: [31] Deleted & bokke001 & 12/23/2008 12:36:00 PM \\
\hline \multicolumn{3}{|l|}{ seem to be } \\
\hline Page 17: [31] Deleted & bokke001 & $12 / 23 / 2008$ 12:36:00 PM \\
\hline
\end{tabular}

Page 17: [31] Deleted
observed

bokke001

$12 / 23 / 2008$ 12:36:00 PM observed

\begin{tabular}{ccc}
\hline $\begin{array}{c}\text { Page 17: [31] Deleted } \\
\text { growing broilers }\end{array}$ & bokke001 & 12/23/2008 12:36:00 PM \\
& \\
\hline Page 17: [31] Deleted & bokke001 & $12 / 23 / 2008$ 12:36:00 PM
\end{tabular}

\begin{tabular}{|c|c|c|}
\hline Page 17: [31] Deleted & bokke001 & $12 / 23 / 2008$ 12:36:00 PM \\
\hline
\end{tabular}

\begin{tabular}{ccc} 
Page 17: [32] Deleted & bokke001 & 12/23/2008 12:36:00 PM \\
\hline $\begin{array}{c}\text { Page 17: [32] Deleted } \\
\text { can be considered }\end{array}$ & bokke001 & 12/23/2008 12:36:00 PM \\
\hline
\end{tabular}

E-mail: br.poultsci@bbsrc.ac.uk URL: http://mc.manuscriptcentral.com/cbps 
as

\section{Page 17: [32] Deleted} bokke001

12/23/2008 12:36:00 PM is on average $4.0 \%$ for fast growing broilers

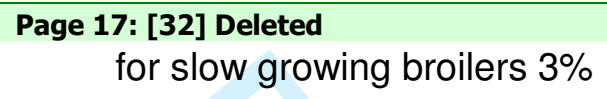

Page 17: [33] Deleted was $3.9 \%$ and 5.6

bokke001

12/23/2008 12:36:00 PM bokke001

$12 / 23 / 2008$ 12:36:00 PM

\section{Page 17: [33] Deleted was $1.4 \%$ and}

bokke001

$12 / 23 / 2008$ 12:36:00 PM

. Samples of conventional broilers showed however resistance against more antibiotics.

In case resistance against a antibiotic was found in samples of both production systems, samples of the conventional production method had a higher resistance than the organic samples

Page 18: [35] Deleted bokke001

12/23/2008 12:36:00 PM . Although based upon only two studies, it seems that organic poultry meat contains fewer residues of antibiotics and has less antibiotic resistant micro-organisms. Campylobacter spp. is a zoonotic pathogen of humans and an important cause of bacterial diarrhoeal disease worldwide

Page 18: [36] Deleted
. Broiler meat is considered one of the most important sources of Campylobacter
spp. infection for humans


. Measurements can be conducted at farms to detect sources of risk but also at broiler product outlets to assess the direct risk for consumers. The percentage of samples of fresh chicken products bought in supermarkets, from poulterer and from butchers spread over the Netherlands and over a whole year which were contaminated with Campylobacter spp. was for conventional broilers $25.9 \%$ in 2003 and $29.3 \%$ in 2004 and for organic broilers $36.3 \%$ in 2003 and $43.9 \%$ in 2004

\section{Page 19: [38] Deleted} bokke001 12/23/2008 12:36:00 PM

. Conventional poultry meat tends to be contaminated with Salmonella more often. The percentage of samples of fresh chicken products taken over a whole year that were contaminated with Salmonella spp. was for conventional broilers $11.2 \%$ in 2003 and $7.4 \%$ in 2004 , and for organic broilers $3.4 \%$ in 2003 and $2.1 \%$ in 2004

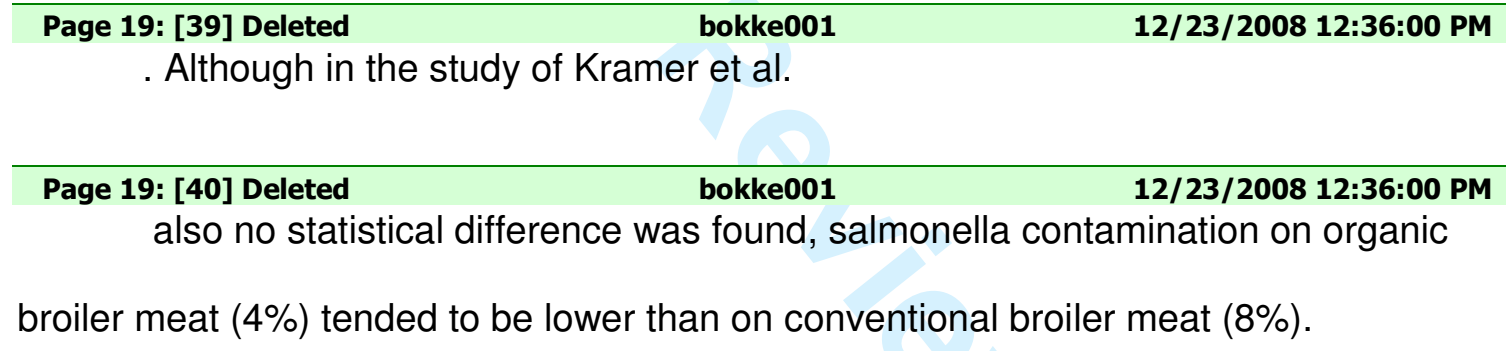

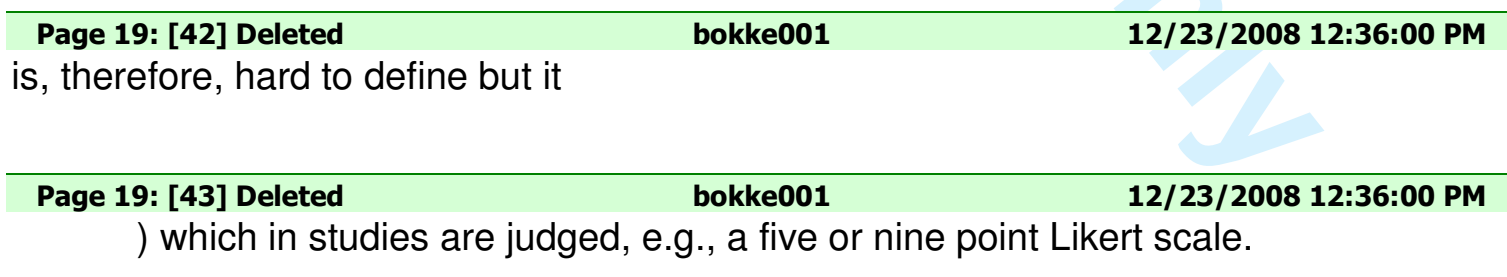

Page 20: [44] Deleted
Van Horne et al. (2003), however, found that breast

12/23/2008 12:36:00 PM

Fanatico et al. (2006) found that fast 
